\title{
White spot syndrome virus: an overview on an emergent concern
}

\author{
Arturo SÁNCHEZ-PAz \\ Centro de Investigaciones Biológicas del Noroeste (CIBNOR), Laboratorio de Análisis Integral Acuícola, \\ Centenario Norte No. 53. Col. Prados del Centenario, Unidad Hermosillo, Hermosillo, Sonora, \\ C.P. 83260 , México
}

(Received 23 June 2009; accepted 24 February 2010)

\begin{abstract}
Viruses are ubiquitous and extremely abundant in the marine environment. One of such marine viruses, the white spot syndrome virus (WSSV), has emerged globally as one of the most prevalent, widespread and lethal for shrimp populations. However, at present there is no treatment available to interfere with the unrestrained occurrence and spread of the disease. The recent progress in molecular biology techniques has made it possible to obtain information on the factors, mechanisms and strategies used by this virus to infect and replicate in susceptible host cells. Yet, further research is still required to fully understand the basic nature of WSSV, its exact life cycle and mode of infection. This information will expand our knowledge and may contribute to developing effective prophylactic or therapeutic measures. This review provides a state-of-the-art overview of the topic, and emphasizes the current progress and future direction for the development of WSSV control strategies.
\end{abstract}

\section{WSSV / crustacean / gene expression / host range / control strategie}

\section{Table of contents}

1. Introduction.

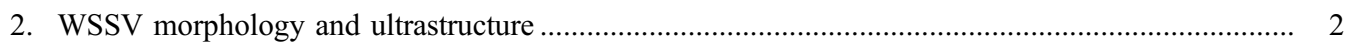

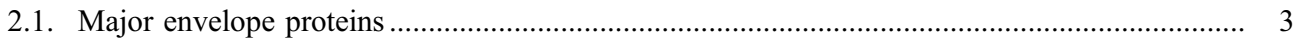

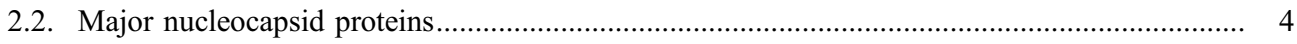

3. WSSV transmission, host range and potential vectors ............................................................... 5

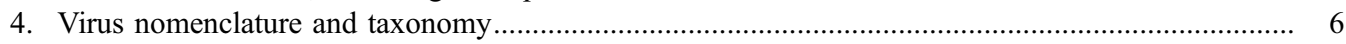

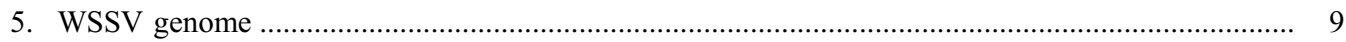

5.1. Time course of viral gene expression ............................................................................ 11

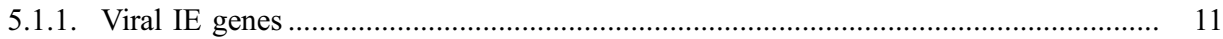

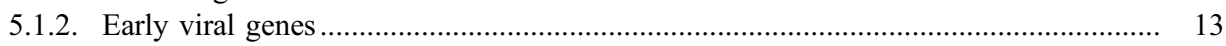

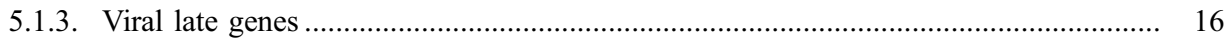

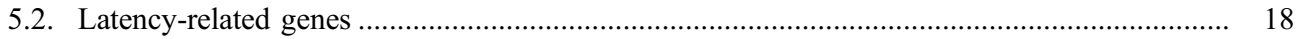

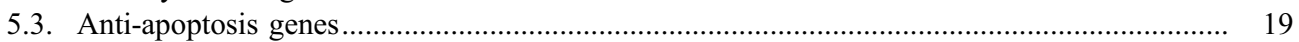

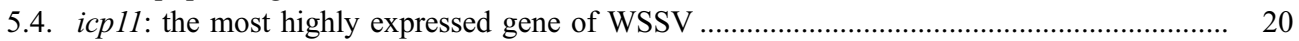

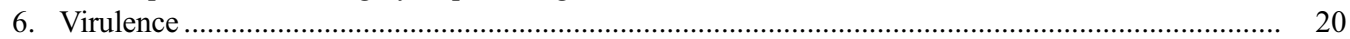

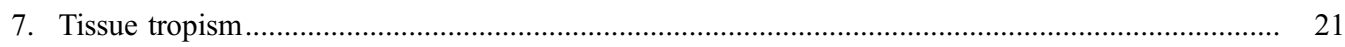

8. Strategies for the control of WSSV ….............................................................................................. 21

\footnotetext{
* Corresponding author: asanchez04@cibnor.mx

This is an Open Access article distributed under the terms of the Creative Commons Attribution-Noncommercial License (http://creativecommons.org/licenses/by-nc/3.0/), which permits unrestricted use, distribution, and reproduction in any noncommercial medium, provided the original work is properly cited.
} 


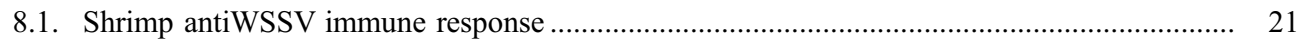

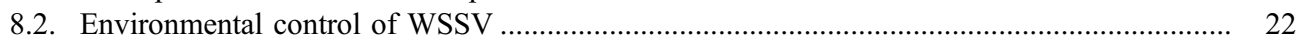

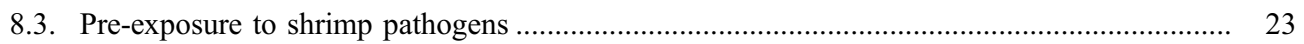

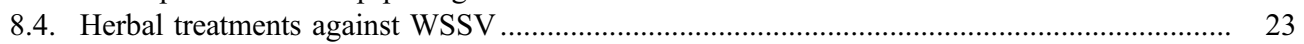

8.5. Vaccination trials to protect shrimp against WSSV .......................................................... 24

8.6. Nucleic acid-based vaccines as a novel approach against WSSV ........................................ 25

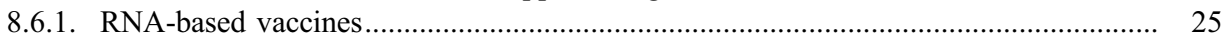

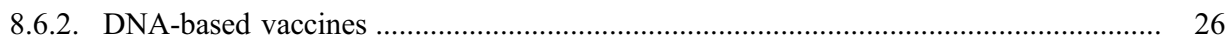

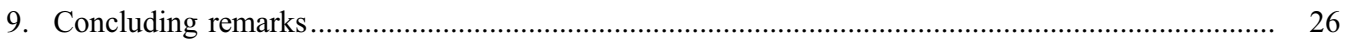

\section{INTRODUCTION}

Before the late $1980 \mathrm{~s}$, marine viruses were considered ecologically unimportant since their concentration was underestimated. However subsequent studies revealed that each milliliter of seawater may contain millions of virus-like particles, and now it is widely accepted that viruses are by far the most abundant "lifeforms" in the oceans, playing important roles in geochemical cycles and as a reservoir for the greatest genetic diversity on Earth [120]. Even though a significant number of viral infections occur in the oceans every day, our knowledge about the modes of infection and transmission, or the natural reservoirs of most of these viruses is still scarce. Nevertheless, a number of important contributions to the current knowledge of viral diseases in marine organisms stems from their adverse effects on some of the main cultivated species.

Among the more lethal viruses infecting Penaeid shrimp, the white spot syndrome virus (WSSV), a rapidly replicating and extremely virulent shrimp pathogen, has emerged globally as one of the most prevalent and widespread. It was first detected in Taiwan in 1992, and then it spread to Japan and almost all Asian countries. The first diagnosed case of WSSV in the Americas occurred in 1995 in a South Texas shrimp farm, and it was suggested that the most probable route for its introduction was through an Asian imported frozen-bait shrimp commodity [35]. In February 1999, the virus caused massive mortalities in some farms in Ecuador [28], while the most recent outbreak in an area with WSSV-free status according to the World
Organization for Animal Health (OIE) criteria, occurred in Brazil in $2005^{1}$.

WSSV-infected shrimp may rapidly develop white spots (ranging from $0.5-3.0 \mathrm{~mm}$ in diameter) on the exoskeleton, appendages and inside the epidermis. Since these spots are not always present, and since similar spots can be produced by some bacteria, high alkalinity and stress, they are not considered a reliable sign for preliminary diagnosis of this disease.

Other signs of WSSV include lethargy, sudden reduction in food consumption, red discoloration of body and appendages and a loose cuticle.

\section{WSSV MORPHOLOGY AND ULTRASTRUCTURE}

To date the morphology and ultrastructure of WSSV is not yet fully understood; however, several characteristics of this virus have emerged in recent years. It has been observed that the WSSV virions show an ovoid to bacillar morphology with a long envelope extension at one extremity (Fig. 1), whose function and structure remains undefined [24]. The WSSV size ranges between 210 and $420 \mathrm{~nm}$ in length and $70-167 \mathrm{~nm}$ in diameter $[31,79]$. The viral envelope is $6-7 \mathrm{~nm}$ thick and has the structure

\footnotetext{
${ }^{1}$ APHIS-USDA, Impact worksheet white spot disease in Brazil, in: APHIS-USDA Impact Worksheet [on line] (2005) http://www.aphis.usda. gov/vs/ceah/cei/taf/iw_2005_files/foreign/whitespot brazil_012705_files/WhitespotdiseaseBrazil012105. htm [consulted 8 January 2010].
} 


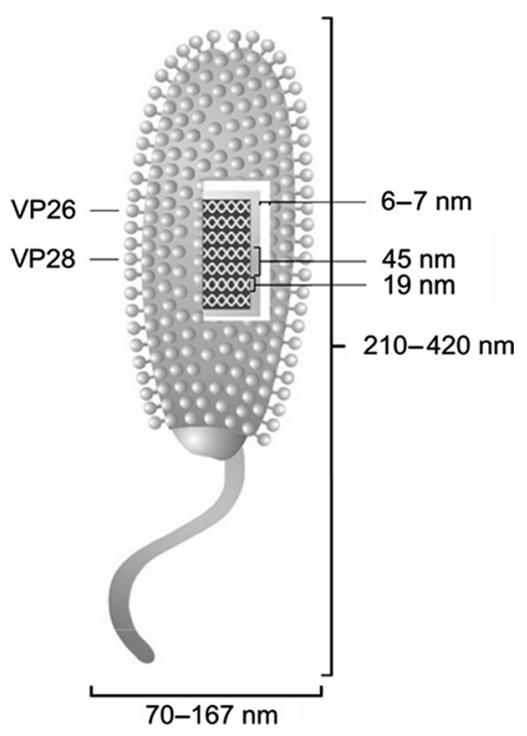

Figure 1. Schematic representation of the morphology of the WSSV viral particle. See [40] for a description of the ultrastructural analysis of the WSSV viral particles. See [123] for a detailed description of the localization and crystal structure of VP26 and VP28.

of an apparently lipidic bilayer membrane, with an area between the envelope and the nucleocapsid varying between 2 and $7.5 \mathrm{~nm}$. The nucleocapsid dimensions are 180-420 in length and $54-85 \mathrm{~nm}$ in diameter indicating that it is tightly packed within the virion [24]. Analysis by TEM of purified WSSV particles showed that the nucleocapsid surface is composed of 15 vertical helices located through the long axis of the nucleocapsid core. Each helix is composed of 13 to 15 capsomers, each of which is $8 \mathrm{~nm}$ in diameter. The size of each helix and striation is $19 \times 80$ and $8 \times 80 \mathrm{~nm}$, respectively. The spacing between each helix is $7 \mathrm{~nm}$, while the two striations with each helix are separated by $3 \mathrm{~nm}$ [40].

A virion is formed by a complex of macromolecules specificly folded and assembled for the protection and delivery of viral genomes. Amongst the entire set of macromolecules, structural proteins are particularly important; however, it is not an easy task to identify structural proteins with conventional tools. In the case of WSSV, different approaches have been used to identify structural proteins: (1) traditional methodologies, such as SDS-PAGE coupled with Western blotting and/or protein $\mathrm{N}$-terminal sequencing, and SDS-PAGE and mass spectrometry [172]; (2) molecular biology methodologies, such as gene cloning and production of recombinant proteins [7]; and (3) novel, more comprehensive and global approaches, such as proteomics [124]. The information available so far indicates that WSSV must be assembled by at least 58 structural proteins [64], several of which have been extensively studied providing a more comprehensive image of its ultrastructure.

Since the purpose of this review is to highlight the developments in WSSV research, we will summarize the main characteristics of some of the best studied WSSV structural proteins, which exhibit very unique characteristics.

\subsection{Major envelope proteins}

The WSSV viral envelope consists of at least 35 different proteins [69], of which VP28 and VP26 are the most abundant, accounting for approximately $60 \%$ of the envelope [123]. VP28, encoded by open reading frame (ORF) 421 (wsv421), is the major envelope protein and several studies suggest that VP28 may play a crucial role in the initial steps of systemic WSSV infection in shrimp [132]. Furthermore, there is evidence that WSSV VP28 plays an important role in the infection process as an attachment protein, binding the virus to shrimp cells, and helping it to enter into the cytoplasm [167]. It has been assumed that VP28 may contribute importantly to the recognition of receptors at the shrimp cell surface due to some potential glycosylation sites [124]; however, this has not yet been demonstrated.

VP26, the product encoded by wsv311 gene, was first identified as being associated to the nucleocapsid [133]. Two years later, it was demonstrated that an ORF ( $p 22$ gene) encodes a WSSV envelope protein [171]. A comparative analysis of genomic sequences showed that $p 22$ was identical to VP26, which is located in the space between the envelope and the nucleocapsid acting as a linker protein. It is likely that the 
N-terminus of VP26 (a strongly hydrophobic region) anchors in the envelope, while the C-terminus (containing a hydrophilic sequence) is bound to the nucleocapsid. In addition, VP26 is capable of binding to actin or actin-associated proteins. It is clear now, that after internalization into the host cell, animal viruses must be transported near the site of transcription and replication, where its genome is delivered. Since free diffusion of large molecules is restricted to the cytoplasm due to its density, viruses interact directly with the cytoskeletal transport machinery to reach its target. Thus, it has been suggested that as a major component of the viral nucleocapsid, VP26 may help WSSV to move toward the nucleus by interacting with actin or cellular actin-binding proteins [162].

It was recently found that both VP28 and VP26 naturally form projected trimers in the viral envelope, and may have an important role on the infective interaction among the viral envelope membrane and the host cell receptors. All enveloped viruses known today gain entry into the cytoplasm of host cells by fusion of their lipid envelope with the host cell membrane. In this case, both WSSV VP28 and VP26 exhibit an architecture similar to the structure of other viral envelope fusion proteins [162].

A computer-assisted analysis of the amino acid sequence of the envelope proteins VP28 and VP26, and the nucleocapsid protein VP24 (wsv002), revealed high homology and conserved domains among these structural proteins. Such similarities may be the result of a gene duplication event, which could be supported by the fact that these genes are encoded by an ORF of approximately the same size $(\sim 206$ amino acids, aa). As highlighted, the fact that proteins with high degrees of amino acid similarity show different functions in the virion was unexpected; this may be the result of gene divergence [134].

To date, at least $6 \mathrm{WSSV}$ envelope proteins (VP31, VP36A, VP36B, VP110, VP187, and VP281) have been reported to contain a cell attachment signature, termed the RGD motif, characterized by an Arg-Gly-Asp sequence, which seems to be involved in virus binding to cell surface integrins. Since the extracellular domains of many integrins have the ability to bind to the RGD motif, they have emerged as attachment or "post-attachment" receptors or co-receptors of a large number of viruses. This finding may suggest that WSSV entry into the host cell may be mediated by viral attachment protein sequences on the surface of the virus particle and virus receptors, as integrins, expressed on the target cell. However, it has been reported that a synthetic peptide containing the RGD motif did not inhibit the infection of WSSV, suggesting that integrins of the host cell are not fully recognized by WSSV as a potential receptor to gain entry into host cells, and that WSSV may use alternative cell receptors for entry into cells [45]. However the critical role of threonine (T) at the fourth position (RGDT) of the attachment motif for proteinintegrin interaction via the RGD motif has been reported. Therefore, only VP31 (wsv340) and VP36A (wsv306) exhibit a RGDT motif, which may facilitate an interaction with integrins to cause a receptive cellular state for infection [124].

With the completion of the WSSV genome sequence, considerable attention was focused on wsv001, which encodes a collagen-like protein (WSSV-CLP) (VP1684). The presence of collagen in viruses has been rarely reported. In this study, WSSV-CLP was purified and treated with N-glycopeptidase $\mathrm{F}$ to determine its glycosylation status. A decrease of its mass was observed, indicating thus that this protein is N-glycosylated, a post-translational modification not detected before in any other WSSV protein [62].

\subsection{Major nucleocapsid proteins}

Proteins constituting the WSSV nucleocapsid are by far less well understood than those found on the viral envelope. VP15, the gene product encoded by $w s v 214$, has been reported as one of the major structural proteins located in the nucleocapsid. Recent work has shown that VP15 encodes a putative 80 aa peptide, comprised of a significant amount of basic amino acids $(44.2 \%)$ and serines $(24.6 \%)$, a characteristic shared by several DNA-binding proteins 
$[153,169]$. Experimental evidence suggests that VP15 has the capability of binding doublestranded DNA in a non-specific manner, but showing a strong preference to binding supercoiled DNA, suggesting a key role of VP15 in the packaging of the WSSV genome in the nucleocapsid. Furthermore, it is now recognized that VP15 interacts with itself, but not with other major structural proteins of the virion, which might be related to the nucleocapsid assembly process [153].

Most of the animal DNA viruses replicate in the cell nucleus by importing their DNA into the nucleus either packaged into the virion along with a virally encoded protease that disassembles the virion and exposes a nuclear localization signal (NLS) that is tightly bound to the DNA, or packaged with cellular proteins that modify viral proteins to create a functional NLS. In contrast large viruses locate the nuclear pore and then release their DNA associated with NLS-bearing structural proteins, to facilitate its entry into the nucleus. Experimental studies have shown that the N-terminus of VP35 contains two potential clusters of four amino acids $\left({ }^{24} \mathrm{KRKR}^{27},{ }^{53} \mathrm{KRPR}^{56}\right)$ resembling some NLS that have already been characterized in detail. Subcellular distribution of VP35 showed that it targets the nucleus. When the four basic amino acids of these motifs were replaced with AAAA, the mutant protein remained totally cytoplasmic, indicating its function as an NLS of WSSV. However, it is not fully demonstrated if these sequences constitute the entire NLS or if they are a crucial part of a bigger signal sequence [13].

One of the most distinctive features of the WSSV genome is the occurrence of $w s v 360$, a giant sequence of $18234 \mathrm{nt}$ encoding for a 6077 aa protein, called VP664, which is located in the nucleocapsid, and distributed with a periodicity that matches the characteristic stacked ring subunits that appear as striations. As in other WSSV structural proteins, a time course analysis of VP664 by RT-PCR showed that this transcript was actively transcribed $12 \mathrm{~h}$ post infection (h p.i.), suggesting that this protein should contribute to the assembly and morphogenesis of the virion [56]. Besides this function, VP664 exhibits a unique feature among viral structural proteins: it is the largest protein ever found in viruses. The largest protein previously identified in any biological entity was connectin (titin), a giant filamentous protein (38138 aa) found in vertebrate striated muscle [2]. However, large proteins are much less common in viruses, and so far there are no other known viral proteins whose size comes close to that of WSSV VP664 [56].

It was reported that VP51 and VP76 (wsv308 and wsv220) are located on the viral envelope, as observed in some studies related to WSSV structural proteins [39, 42]. Recently, however, VP51 and VP76 were reported as minor structural components associated with virus nucleocapsids [158], and their functions still remain unknown.

\section{WSSV TRANSMISSION, HOST RANGE AND POTENTIAL VECTORS}

Perhaps, the most crucial stage in the dynamics of virus infections is its mode of transmission. In general, transmission of viruses can occur through two pathways: horizontally (transmitted among individuals of the same generation by direct contact, or indirectly, by ingestion of infected organisms), and vertically (virus is passed from an infected female parent to her $F_{1}$ progeny). To date, the transmission of WSSV by ingestion of infected tissue, direct exposure of body surfaces to virus particles in the water, or injection of cell-free extract of infected tissue has been reported [10, 25]. However, some modes of transmission are more effective than others as Lots and Soto demonstrated: transmission by ingestion of infected tissue is over an order of magnitude higher than cohabitation transmission [78]. Besides, there is evidence that WSSV can be vertically transmitted. Likewise, by using in situ hybridization and TEM, viral particles were only detected in the connective tissue layer surrounding the seminiferous tubules in males, while in females viral particles were observed in the ovary, follicle cells, oogonia, oocytes and connective tissue cells. Furthermore, no virus infection was found in mature eggs, which may imply that infected eggs died by the virus before maturation [77]. 
Knowledge of the WSSV host range is an important task because it might help to prevent or restrict its spread, and could help to evaluate potential damage to wild populations. An unexpected feature of WSSV is its wide range of potential hosts. To date, more than 93 species of arthropods have been reported as hosts or carriers of WSSV either from culture facilities, the wild or experimental infection. Table I shows a list of host species for which scientific evidence supports susceptibility either by natural or experimental infection to WSSV. In addition, the occurrence of WSSV in rotifer eggs, identified as Brachionus urceus, from shrimp culture-pond sediments, was detected by PCRdot blot hybridization. Since WSSV was detected in previously chlorinated eggs, it was hypothesized that WSSV does not bind to the egg surface, but is possibly transmitted vertically. Cell membranes from B. urceus, specifically bind purified WSSV in vitro, suggesting that this rotifer may be a passive host of WSSV, and may represent a feasible WSSV vector for crustaceans [165].

Aditionally, it has been found that WSSV could be accumulated in the digestive tract of polychaetes, where they remain infectious, and thus, these worms may serve as a passive vector of WSSV in aquatic systems. Furthermore, it was demonstrated that shrimp can be horizontally infected via ingestion of WSSVinfected polychaete worms, attaining prevalence rates of up to $83 \%$ [139].

Finally, there are few reports of seabirds serving as potential sources of viral transmission. Thus, white leghorn chickens (Gallus domesticus) and captive seagulls (Larus atricilla) were fed with WSSV-infected shrimp carcasses and WSSV DNA was detected by standard PCR in both seagull (for up to $72 \mathrm{~h}$ ) and chicken feces extracts (for up to $57 \mathrm{~h}$ ). However, injection of an inoculum prepared from bird fecal material containing the virus to healthy shrimp demonstrated that WSSV was noninfectious, since no mortalities due to WSSV infection were observed in shrimp [135]. Indeed, such studies exhibit that the knowledge about WSSV host range may be deficient by the limited scope of surveillance.

\section{VIRUS NOMENCLATURE AND TAXONOMY}

Since its appearance in 1992, the causative viral agent of this disease has been named in several ways. Originally, the etiological agent was described as an enveloped bacilliform pathogenic virus, named RV-PJ (rod-shaped nuclear virus of $P$. japonicus), and subsequently it was renamed Penaeid rod-shaped DNA virus (PRDV) [43]. The hypodermal and hematopoietic necrosis virus (HHNBV) is considered as the etiological agent of the prawn explosive epidemic disease (SEED) suffered in China during 1993-1994 [5], and a year later it was informally named as systemic ectodermal and mesodermal baculovirus (SEMBV) in Thailand due to its morphology, size, and histopathological profile [156]. The virus has also been taxonomically affiliated as the following: Chinese baculovirus, red disease, white spot disease, and white spot baculovirus. However, presently the virus is referred to as WSSV.

Viral taxonomy places the viruses in categories with a hierarchical structure, the ranks being the species, genus, family and order. Thus, in 1995 it was proposed that based on its morphology, size, site of assembly, cellular pathology, and nucleic acid content, WSSV should be assigned to the subfamily Nudibaculovirinae, family Baculoviridae, where it would be formally named PmNOBII, as the second non-occluded baculovirus (NOB) reported for a shrimp species (P. monodon) [157]. During the same year, a similar isolate was considered as a different virus, and it was named PmNOBIII [140]. However, changes in nomenclature removed the genus NOB and the subfamily Nudibaculovirinae, classifying WSSV into the unassigned invertebrate viruses group, mainly due to the lack of molecular information [77].

Different approaches helped to resolve some difficulties on the taxonomic status of WSSV. Thus, studies based on the ribonucleotide reductase ( $r r 1$ and $r r 2)$ genes [130], the VP26 and VP28 DNA sequences [129], the finding of promoters of the WSSV $r r$ genes not found in baculoviruses [134], and a phylogenetic analysis 
Table I. The known host species reported to be naturally or experimentally infected with WSSV.

\begin{tabular}{|c|c|c|c|c|c|}
\hline Phylum & Order & Family & Species & Type of infection & Reference \\
\hline \multirow[t]{2}{*}{ Arthropoda } & Anostraca & Artemiidae & Artemia sp. & $\mathrm{E}(\mathrm{PO}, \mathrm{IMI})$ & {$[110]$} \\
\hline & & & A. franciscana & $\mathrm{E}(\mathrm{PO})$ & {$[61]$} \\
\hline Arthropoda & Calanoida & Pseudodiaptomidae & Schmackeria dubia & $\mathrm{N}$ & [76] \\
\hline \multirow{2}{*}{ Arthropoda } & Decapoda & Alpheidae & Alpheus brevicristatus & $\mathrm{N}$ & [122] \\
\hline & & & A. lobidens & $\mathrm{N}$ & {$[122]$} \\
\hline \multirow[t]{3}{*}{ Arthropoda } & Decapoda & Astacidae & Astacus astacus & E(IMI) & {$[46]$} \\
\hline & & & A. leptodactylus & $\mathrm{E}(\mathrm{PO}, \mathrm{IMI})$ & [20] \\
\hline & & & Pacifastacus leniusculus & $\mathrm{E}(\mathrm{IMI})$ & [44] \\
\hline \multirow[t]{2}{*}{ Arthropoda } & Decapoda & Calappidae & Calappa lophos & $\mathrm{E}(\mathrm{PO})$ & [147] \\
\hline & & & C. philargius & $\mathrm{E}(\mathrm{PO}, \mathrm{IMI})$ & [107] \\
\hline Arthropoda & Decapoda & Callianassidae & Callianassa $\mathrm{sp}$. & $\mathrm{N}$ & {$[76]$} \\
\hline Arthropoda & Decapoda & Cancridae & Cancer pagurus & $\mathrm{E}(\mathrm{PO}, \mathrm{IMI})$ & [20] \\
\hline \multirow[t]{3}{*}{ Arthropoda } & Decapoda & Cambaridae & Orconectes limosus & $\mathrm{E}(\mathrm{PO}, \mathrm{IMI})$ & [20] \\
\hline & & & O. punctimanus & $\mathrm{N}$ & [145] \\
\hline & & & Procambarus clarkii & E(IMI) & {$[40]$} \\
\hline Arthropoda & Decapoda & Dorippidae & Paradorippe granulata & $\mathrm{E}(\mathrm{PO}, \mathrm{IMI})$ & [107] \\
\hline Arthropoda & Decapoda & Eriphiidae & Menippe rumphii & $\mathrm{E}(\mathrm{PO}, \mathrm{IMI})$ & {$[107]$} \\
\hline \multirow{3}{*}{ Arthropoda } & Decapoda & Grapsidae & Grapsus albolineatus & $\mathrm{E}(\mathrm{PO}, \mathrm{IMI})$ & {$[107]$} \\
\hline & & & Metopograpsus messor & $\mathrm{N} / \mathrm{E}(\mathrm{PO})$ & $\mathrm{N}:[116]$ \\
\hline & & & & & E: [98] \\
\hline Arthropoda & Decapoda & Leucosiidae & Philyra syndactyla & $\mathrm{E}(\mathrm{PO}, \mathrm{IMI})$ & {$[107]$} \\
\hline Arthropoda & Decapoda & Lithodidae & Lithodes maja & $\mathrm{E}(\mathrm{PO}, \mathrm{IMI})$ & [107] \\
\hline Arthropoda & Decapoda & Majidae & Doclea hybrida & $\mathrm{E}(\mathrm{PO}, \mathrm{IMI})$ & [107] \\
\hline \multirow[t]{2}{*}{ Arthropoda } & Decapoda & Matutidae & Matuta miersi & $\mathrm{N}$ & {$[107]$} \\
\hline & & & M. planipes & $\mathrm{N}$ & [91] \\
\hline \multirow[t]{3}{*}{ Arthropoda } & Decapoda & Ocypodidae & Gelasimus marionis nitidu & $\mathrm{N}$ & [116] \\
\hline & & & Macrophthalmus sulcatus & $\mathrm{N}$ & [116] \\
\hline & & & Uca pugilator & E(IMI) & [48] \\
\hline \multirow{5}{*}{ Arthropoda } & Decapoda & Palaemonidae & Exopalaemon orientis & $\mathrm{E}(\mathrm{PO})$ & [9] \\
\hline & & & Macrobrachium idella & E(PO, IMI, IN) & [109] \\
\hline & & & M. lamarrei & E(PO, IMI, IN) & [109] \\
\hline & & & M. rosenbergii & $\mathrm{N} / \mathrm{E}(\mathrm{IN})$ & N, E: [94] \\
\hline & & & Palaemon adspersus & $\mathrm{E}(\mathrm{PO}, \mathrm{IMI})$ & {$[20]$} \\
\hline \multirow[t]{6}{*}{ Arthropoda } & Decapoda & Palinuridae & Panulirus homarus & $\mathrm{E}(\mathrm{IMI})$ & [98] \\
\hline & & & P. longipes & $\mathrm{E}(\mathrm{PO})$ & {$[147]$} \\
\hline & & & P. ornatus & E(IMI) & {$[98]$} \\
\hline & & & P. penicillatus & $\mathrm{E}(\mathrm{PO})$ & [147] \\
\hline & & & P. polyphagus & E(IMI) & [98] \\
\hline & & & $P$. versicolor & $\mathrm{E}(\mathrm{PO})$ & [9] \\
\hline \multirow[t]{2}{*}{ Arthropoda } & Decapoda & Parastacidae & Cherax destructor albidus & E(IMI) & {$[26]$} \\
\hline & & & C. quadricarinatus & E(IMI) & [117] \\
\hline \multirow[t]{2}{*}{ Arthropoda } & Decapoda & Parathelphusidae & Parathelphusa hydrodomous & $\mathrm{E}(\mathrm{PO}, \mathrm{IMI})$ & [108] \\
\hline & & & P. pulvinata & $\mathrm{E}(\mathrm{PO}, \mathrm{IMI})$ & [108] \\
\hline Arthropoda & Decapoda & Parthenopidae & Parthenope prensor & $\mathrm{E}(\mathrm{PO}, \mathrm{IMI})$ & {$[107]$} \\
\hline \multirow[t]{3}{*}{ Arthropoda } & Decapoda & Penaeideae & Metapenaeus brevicornis & $\mathrm{E}(\mathrm{IMI})$ & $\mathrm{E}:[50]$ \\
\hline & & & M. dobsoni & N/E(PO) & $\mathrm{N}:[116]$ \\
\hline & & & & & E: $[98]$ \\
\hline
\end{tabular}


Table I. Continued.

\begin{tabular}{|c|c|c|c|c|c|}
\hline Phylum & Order & Family & Species & Type of infection & Reference \\
\hline & & & M. ensis & $\mathrm{N} / \mathrm{E}(\mathrm{PO})$ & $\mathrm{N}:[76]$ \\
\hline & & & & & $\mathrm{E}:[9]$ \\
\hline & & & M. lysianassa & $\mathrm{N}$ & {$[34]$} \\
\hline & & & M. monoceros & E(IMI, PO) & [98] \\
\hline & & & Parapeneopsis stylifera & $\mathrm{N}$ & [116] \\
\hline & & & Penaeus aztecus & $\mathrm{N} / \mathrm{E}$ & $\mathrm{N}:[67]$ \\
\hline & & & & & E: [27] \\
\hline & & & P. chinensis & $\mathrm{N} / \mathrm{E}$ & $\mathrm{N}:[5]$ \\
\hline & & & & & E: [41] \\
\hline & & & P. duorarum & N/E (PO) & $\mathrm{N}:[67]$ \\
\hline & & & & & E: [144] \\
\hline & & & P. indicus & N/E (PO) & $\mathrm{N}:[97]$ \\
\hline & & & & & $\mathrm{E}:[110]$ \\
\hline & & & P. japonicus & N/E (PO) & $\mathrm{N}:[88]$ \\
\hline & & & & & E: [17] \\
\hline & & & P. merguiensis & $\mathrm{N}$ & {$[144]$} \\
\hline & & & P. monodon & $\mathrm{N} / \mathrm{E}$ & $\mathrm{N}:[18]$ \\
\hline & & & & & E: [10] \\
\hline & & & P. penicillatus & $\mathrm{N} / \mathrm{E}$ & $\mathrm{N}:[18]$ \\
\hline & & & & & E: [18] \\
\hline & & & P. schmitti & E(IMI) & {$[128]$} \\
\hline & & & P. semisulcatus & $\mathrm{N} / \mathrm{E}$ & $\mathrm{N}:[76]$ \\
\hline & & & & & E: [97] \\
\hline & & & P. setiferus & $\mathrm{N} / \mathrm{E}(\mathrm{PO})$ & $\mathrm{N}:[67]$ \\
\hline & & & & & E: [68] \\
\hline & & & P. stylirostris & N/E (PO, IMI, IN) & $\mathrm{N}:[67]$ \\
\hline & & & & & E: [25] \\
\hline & & & P. vannamei & N/E(IMI) & $\mathrm{N}:[67]$ \\
\hline & & & & & E: [23] \\
\hline & & & Trachypenaeus curvirostris & $\mathrm{E}(\mathrm{PO})$ & $\mathrm{E}:[9]$ \\
\hline \multirow[t]{16}{*}{ Arthropoda } & Decapoda & Portunidae & Callinectes arcuatus & $\mathrm{N}$ & {$[28]$} \\
\hline & & & C. sapidus & $\mathrm{N}$ & {$[11]$} \\
\hline & & & Carcinus maenas & $\mathrm{E}(\mathrm{PO}, \mathrm{IMI})$ & [20] \\
\hline & & & Charybdis annulata & $\mathrm{N}$ & {$[116]$} \\
\hline & & & Ch. cruciata & $\mathrm{N}$ & [116] \\
\hline & & & Ch. granulata & $\mathrm{E}(\mathrm{PO})$ & [9] \\
\hline & & & Ch. feriatus & $\mathrm{N}$ & [76] \\
\hline & & & Ch. japonica & $\mathrm{N}$ & [83] \\
\hline & & & Ch. lucifera & N/E(PO, IMI) & $\mathrm{N}:[91]$ \\
\hline & & & & & E: [107] \\
\hline & & & Ch. natator & $\mathrm{E}(\mathrm{PO}, \mathrm{IMI})$ & {$[107]$} \\
\hline & & & Liocarcinus depurator & $\mathrm{E}(\mathrm{PO}, \mathrm{IMI})$ & [20] \\
\hline & & & Lio. puber & $\mathrm{E}(\mathrm{PO}, \mathrm{IMI})$ & [20] \\
\hline & & & Podophthalmus vigil & $\mathrm{E}(\mathrm{PO}, \mathrm{IMI})$ & {$[107]$} \\
\hline & & & Portunus pelagicus & N/E(PO, IMI) & $\mathrm{N}:[76]$ \\
\hline & & & & & E: [119] \\
\hline
\end{tabular}


Table I. Continued.

\begin{tabular}{|c|c|c|c|c|c|}
\hline Phylum & Order & Family & Species & Type of infection & Reference \\
\hline & & & P. sanguinolentus & $\mathrm{N} / \mathrm{E}(\mathrm{PO})$ & $\mathrm{N}:[76]$ \\
\hline & & & & & $\mathrm{E}:[9]$ \\
\hline & & & Scylla serrata & N/E(PO, IMI) & $\mathrm{N}:[76]$ \\
\hline & & & & & E: [119] \\
\hline & & & S. tranquebarica & $\mathrm{E}(\mathrm{IMI})$ & {$[98]$} \\
\hline & & & Thalamita danae & $\mathrm{N}$ & [116] \\
\hline Arthropoda & Decapoda & Scyllaridae & Scyllarus arctus & $\mathrm{E}(\mathrm{PO}, \mathrm{IMI})$ & {$[20]$} \\
\hline \multirow[t]{2}{*}{ Arthropoda } & Decapoda & Sergestidae & Acetes sp. & N/E(PO, IMI, IN) & $\mathrm{N}:[116]$ \\
\hline & & & & & E: [119] \\
\hline Arthropoda & Decapoda & Sesarmidae & Sesarma oceanica & $\mathrm{N}$ & {$[91]$} \\
\hline Arthropoda & Decapoda & Solenoceridae & Solenocera indica & $\mathrm{N}$ & [116] \\
\hline \multirow[t]{2}{*}{ Arthropoda } & Decapoda & Varunidae & Helice tridens & $\mathrm{N}$ & [76] \\
\hline & & & Pseudograpsus intermedius & $\mathrm{N}$ & [116] \\
\hline \multirow[t]{4}{*}{ Arthropoda } & Decapoda & Xanthidae & Atergatis integerrimus & $\mathrm{E}(\mathrm{PO}, \mathrm{IMI})$ & [107] \\
\hline & & & Demania splendida & $\mathrm{E}(\mathrm{PO}, \mathrm{IMI})$ & {$[107]$} \\
\hline & & & Halimede ochtodes & $\mathrm{E}(\mathrm{PO}, \mathrm{IMI})$ & {$[107]$} \\
\hline & & & Liagore rubromaculata & $\mathrm{E}(\mathrm{PO}, \mathrm{IMI})$ & {$[107]$} \\
\hline Arthropoda & Diptera & Ephydridae & Ephydrida sp. & $\mathrm{N}$ & {$[76]$} \\
\hline Arthropoda & Stomatopoda & Squillidae & Squilla mantis & $\mathrm{N}$ & [116] \\
\hline Annelida & Eunicida & Eunicidae & Marphysa gravelyi & $\mathrm{N}$ & [139] \\
\hline Chaetognatha & - & - & - & $\mathrm{N}$ & a \\
\hline Rotifera & Ploimida & Brachionidae & Brachionus urceus & $\mathrm{N}$ & [165] \\
\hline
\end{tabular}

${ }^{a}$ Ramírez-Douriet C., De Silva-Dávila R., Méndez-Lozano J., et al., White spot syndrome virus detection in zooplankton of coastal lagoons and shrimp commercial ponds in Sinaloa, Mexico, in: The American Fisheries Society (Ed.), 135th Annual Meeting of the American Fisheries Society Alaska, 2005.

comparing the WSSV protein kinase (PK) gene with PK from several viruses and eukaryotes, finally separated WSSV from baculoviruses [131]. As a result, WSSV was proposed as either a representative of a new genus (Whispovirus) within the Baculoviridae, or a representative of a new virus family, Whispoviridae [129]. Since 2002 the ICTV included WSSV as the type species of the the genus Whispovirus, family Nimaviridae. The family name reflects the most notable physical feature of the virus: a tail-like polar projection ("nima" is Latin for "thread"). Thus, the WSSV became the sole species of a new monotypic family called Nimaviridae (genus Whispovirus) [85].

\section{WSSV GENOME}

It was until 1997 that the WSSV DNA was isolated for the first time. It was found that the viral genome is a double-stranded circular DNA molecule. During 2001, two complete WSSV genome sequences, from Thailand and China isolates (WSSV-Th and WSSV-Cn, respectively), were published [133, 166]. In 2005, the full length viral genome sequence of a Taiwan isolate (WSSV-Tw) was submitted to GenBank (GenBank accession number: AF440570). These sequences show variations in size (292 967; 305107 ; and $307287 \mathrm{~kb}$, for the Thailand, China and Taiwan isolates, respectively), mainly due to several small insertions and one large $(\sim 14 \mathrm{~kb})$ deletion, exhibiting a degree of genetic instability.

A total of 684,531 and 507 putative ORF have been identified on the WSSV-Th, WSSV-Cn and WSSV-Tn isolates genome, respectively. From these putative ORF, located on both DNA strands, only 184 (WSSV-Th) and 181 (WSSV-Cn) are likely to encode nearly 50 or more functional proteins. Full 
characterization of the genome has been a demanding task due to the lack of significant sequence homology of the proteins encoded by the WSSV ORF. In addition, some of the information available is contradictory. Thus, there are reports suggesting the existence of potential polyadenylation sites for most of the ORF reported, which are located downstream of the coding sequence $[133,166]$. In contrast, a relatively high percentage of WSSV structural protein genes lacking an identified polyadenylation signal was found, which may imply that this genome contains polycistronic gene clusters sharing a common poly(A) signal for polyadenylation of each transcript, and then use the internal ribosomal entrance site (IRES) in order to translate each gene [124].

Recently, it was found that the WSSV-Tw genome possesses several structural and nonstructural genes arranged in clusters. At least four of these clusters produce polycistronic mRNA, and one of these clusters (vp31/vp39b/ vp11) produces two transcripts, including a large $3.4-\mathrm{kb}$ polycistronic transcript of all three genes. No monocistronic vp39b mRNA was detected. Transcription and translation assays showed that vp39b and vp31 are independently translated, and that ribosomal reinitiation was not a possible mechanism for vp39b. According to the above mentioned study, an unusually located IRES element was identified in the vp31/vp39b coding region. In addition, it was reported that vp31/vp39b/vp11 is representative of many other WSSV structural/nonstructural gene clusters, and it is likely that such an arrangement may produce polycistronic mRNA, and its translation could be regulated through an IRES mechanism [49].

Nevertheless, the isolates share some genomic characteristics: both WSSV-Th and WSSV-Cn isolates include nine repeat regions dispersed in intergenic regions found in both orientations of the genome, named homologous regions ( $h r s)$ [133, 166]. Each $h r$ contains several (3-8) repeated minifragments with a size ranging between $250-300$ bp. Nucleotide sequence alignment of hrs showed a highly conserved domain in the center of all the repeat units containing an imperfect palindrome. The highly conserved central domain is flanked by two more variable domains [133]. It has been proposed that the WSSV hrs are likely to function as origins of replication (ori), and that some may enhance gene transcription, playing thus fundamental roles in the viral life cycle.

Initial attempts to examine genetic variations among the three reported WSSV isolates with limited discrimination methods, such as RFLP, suggested that isolates are closely related to each other [146]. However, the publication of the complete genome sequences of the isolates, has allowed the possibility to identify variations by computational analysis. Thus, it has been found that the WSSV genome sequences exhibit differences categorized into the following major types [85]:

(1) A large deletion of $13.2 \mathrm{~kb}$ present at an intergenic region in the WSSV-Th genome relative to $\mathrm{WSSV}-\mathrm{Cn}$ and WSSV-Tw;

(2) A genetically variable region of approximately $750 \mathrm{bp}$, found only in the WSSV-Th genome, which could be caused by a recombinatorial event;

(3) An insert of $1337 \mathrm{bp}$ in the WSSV-Tw isolate, with $100 \%$ homology with known transposable elements, both from prokaryotic as well as eukaryotic origin;

(4) Variation in the number of repeat units within homologous regions and direct repeats;

(5) Single nucleotide mutations (SNP and insertions/deletions) randomly distributed over the WSSV genome, except for WSSV-Tw in which nearly $25 \%$ of these mutations occur in coding regions of ORF24, ORF25, ORF30, ORF38 and ORF84.

Thus, the observed variations suggest a geographical spread from a common ancestor from the Taiwan Strait to Thailand between 1992 and 1995 , the given origin to the WSSV-Tw and the WSSV-Cn isolates. Recent studies have shown that isolates from Vietnam (WSSV-Vn) [22] and India (WSSV-In) [95] contain deletions of 
11.5-12.2 and $10.9 \mathrm{~kb}$, respectively. The characteristics of these isolates support the hypothesis of a common ancestor origin, which was subsequently dispersed throughout the world.

Finally, the complete sequences of the three isolates share a $99.32 \% \mathrm{nt}$ identity when the large deletion, the variable region and the transposase sequence are ignored [85].

For convenience, in this work the WSSV genes will be divided in those expressed immediately after infection (early genes) and those transcribed after the onset of viral protein and DNA synthesis.

\subsection{Time course of viral gene expression}

As a rough approximation, during an infection, viral genes are transcribed in an ordered cascade of events, which can be broadly divided into three kinetic phases of gene expression: immediate-early (IE), early (E) and late (L). IE genes are expressed relying primarily on host proteins and factors for their expression, which occur in the absence of viral DNA replication. E gene expression, dependent on the preceding expression of IE genes, mainly encodes enzymes required for viral DNA synthesis, plus a number of proteins that can regulate the expression of L genes. After viral DNA synthesis is initiated, $\mathrm{L}$ genes are expressed and encode enzymes and structural proteins necessary for virion assembly.

\subsubsection{Viral IE genes}

Just as many other dsDNA viruses, WSSV transcribes its genes in a temporal manner. Since IE genes encode proteins involved in activating the expression of viral early and late genes, altering the functions of host genes and eliminating host immune defense, their expression is especially important in determining host range. Thus, the accurate cascade of events controlling viral replication depends strongly on the proper expression of these genes during the early stages of infection [72].

Studies employing cycloheximide (CHX) are particularly useful to dissect out temporal patterns of expression. Since CHX inhibits de novo protein synthesis by preventing translation, accumulation of viral IE transcripts could be expected, because the transcription of all other viral genes requires the synthesis of proteins encoded by IE genes. In fact, transcription during infection in the presence of CHX is the condition that most rigorously defines the IE genes. Hence, the use of appropriate $\mathrm{CHX}$ concentrations to inhibit de novo WSSV protein synthesis in experimentally infected shrimp has been reported. Consequently, three ORF (wsv069, wsv187, and wsv151; also designated as $i e, i e 2$ and $i e 3$ ) were considered as acceptable candidate IE genes since the expression of these genes was not sensitive to CHX treatment. Recent experimental data suggests that the WSSV iel promoter may contain conserved sequences for invertebrate transcriptional recognition, which allows WSSV to infect a wide range of hosts [72].

As previously mentioned, viruses have multiple specific strategies to evade and survive the hostile host immune system. During the last decade a group of transcription factors named Signal Transducers and Activators of Transcription (STAT) were identified in vertebrates. These factors possess the ability to transduce signals from the cell membrane to the nucleus to activate gene transcription, thus bypassing the involvement of secondary messengers. Evidence indicates that STAT proteins are required for innate and adaptive antimicrobial immune responses in both vertebrates and invertebrates. Functional analysis of the WSSV IE iel gene promoter showed that a 23-nt fragment is critical for a strong promoter activity. This cis-acting element contains a sequence (ATTCCTAGAAA) that is recognized, and strongly activated, by the shrimp STAT binding motif, consequently enhancing the expression of viral IE genes [71]. Thus, WSSV annexes the defensive activity of STAT to its benefit. It is now accepted that WSSV reduces STAT transcription in the host [15]. Hence, this may imply that transcription levels above a certain minimum would be beneficial to the virus in order to drive the expression of viral genes such as $i e 1$, while it may also be beneficial to prevent STAT transcription to increase above the basal level to avoid eliciting a global antiviral immune response. 
Table II. WSSV immediate-early (IE) genes expressed during infection.

\begin{tabular}{lcccc}
\hline Gene name & Putative function & Length (amino acids) & Gene expression (h p.i.) & Reference \\
\hline$i e 1$ & Transcription factor & 224 & 2 & {$[72]$} \\
$i e 2$ & No recognizable functional motifs & 108 & 2 & {$[72]$} \\
$i e 3$ & No recognizable functional motifs & 60 & 2 & {$[72]$} \\
wsv051 & Transcription factor & 196 & 1 & {$[58]$} \\
wsv079 & Transcription factor & 511 & 1 & {$[58]$} \\
wsv078 & Low complexity & 398 & 2 & {$[58]$} \\
wsv080 & Unidentified & 129 & 2 & {$[58]$} \\
wsv083 & Serine/threonine (Ser/Thr) kinase & 581 & 1 & {$[58]$} \\
wsv091 & Unidentified & 1145 & 1 & {$[58]$} \\
wsv094 & Unidentified & 163 & 2 & {$[58]$} \\
wsv098 & Low complexity & 168 & 1 & {$[58]$} \\
wsv099 & Low complexity & 102 & 2 & {$[58]$} \\
wsv100 & Transcription factor & 624 & 1 & {$[58]$} \\
wsv101 & Unidentified & 112 & 2 & {$[58]$} \\
wsv103 & Unidentified & 128 & 1 & {$[58]$} \\
wsv108 & Low complexity & 406 & 2 & {$[58]$} \\
wsv178 & Unidentified & 302 & 2 & {$[58]$} \\
wsv238 & VP51A,VP52A/Structure protein & 486 & 1 & {$[54]$} \\
wsv249 & Ubiquitin E3 ligase & 783 & 2 & {$[58]$} \\
wsv360 & VP664/Structure protein & 6077 & {$[56]$} \\
\hline
\end{tabular}

Through the construction of a recombinant baculovirus vector containing a reporter gene under the transcriptional control of the WSSV iel promoter, it was found that iel has a robust promoter activity in insect cells, while its activity showed significant variations through different cell lines. In contrast, with the baculovirus ETL promoter (whose activity in mammalian cells depends on IE genes of the baculovirus), the WSSV iel promoter can directly switch on transgene expression in mammalian cells, suggesting that transcription initiation by the WSSV iel promoter resembles that of eukaryotes [29].

Up to date, 16 ORF have been identified in the WSSV-Ch isolate as IE genes through the use of a gene expression screening method based on the treatment of a primary culture of WSSV-infected crayfish hemocytes with CHX and a WSSV genome tiling microarray. Table II enlists the name and presumed function of the identified WSSV IE genes. Protein domain and motif analysis revealed that some proteins encoded by WSSV IE genes contain motifs that may have functional significance.
At least three different classes of proteins are encoded by the WSSV IE genes: transcription factors, kinase, and ubiquitin E3 ligase. Thus, constructs of a yeast GAL4 DNA binding domain with the DNA fragments of wsv051, wsv069, wsv079 or wsv100 were reported to activate the reporter genes HIS3 and ADE2, suggesting that the four WSSV IE proteins WSV051, WSV069 (IE1), WSV079, and WSV100 may function as transcription factors. In fact, it was found by database searching that WSV051 shares $25 \%$ identity with the BadM/ Rrf2 family transcription factor, WSV79 includes a RING finger region, and WSV100 contains a TAZ zinc finger domain [58]. In addition, IE1 (encoded by iel), described as a C2H2-type zinc finger DNA binding motif, possesses the two functional domains characteristic of transcriptional regulators: a DNA binding domain located within the C-terminal end of the protein, that allows attachment of the transactivator to its target sequence within a gene promoter, and an acidic transactivation domain located on the N-terminal end of the protein that interacts with the transcription machinery [73]. 
Another IE gene, wsv083, is expressed $1 \mathrm{~h}$ p.i., and was predicted, by database searching, to contain a Serine/Threonine (Ser/Thr) kinase domain [58]. Protein phosphorylation in virally infected cells may depend on cellular PK or virally encoded PK [63]. In 2001, a WSSV Ser/Thr PK gene was identified. The WSSV Ser/Thr PK and VP28 genes were reported as being juxtaposed in a tail-to-tail arrangement and separated by $94 \mathrm{nt}$. Besides, it was found that the complete WSSV Ser/Thr PK ORF (2193 nt) encodes a 730 aa putative protein sharing the 12 conserved subdomains characteristic of most PK [131]. However, recent evidence indicates that the WSSV Ser/ Thr PK protein sequence of the catalytic domain was incomplete and incorrectly located. In fact, the most serious objection to the previous findings concerns the fact that subdomains I to $\mathrm{V}$ were situated erroneously in a region that is a large and unique insertion (146 residues) between subdomains V and VI [70]. This insert generates a larger catalytic domain of the WSSV Ser/Thr PK (433 aa) compared to other PK catalytic domains. Coupled in vitro transcription and translation of the WSSV Ser/Thr PK gene generated a protein having an apparent molecular mass of $\sim 87 \mathrm{kDa}$, which is consistent with the predicted size of the full length sequence $(80 \mathrm{kDa})$. However, it is still necessary to establish if this gene encodes a fully functional enzyme. Finally, temporal expression analysis of the WSSV Ser/Thr PK gene by RTPCR in WSSV-infected shrimp samples was first detected at $2 \mathrm{~h}$ p.i. As mentioned above, it was found that the expression of this gene in primary cultured crayfish hemocytes was detected $1 \mathrm{~h}$ p.i. [58]. Differences in the results obtained in both studies may be attributable, in part, to variations in performances between assays, since in the first essay the organism was artificially infected and the samples were obtained from pleopod tissues, while in subsequent studies only primary cultured crayfish hemocytes were infected. This interpretation of data seems reasonable since it has been reported that in the cuticular epidermis (including the epithelium of the eye stalk, appendages and the epithelium under the carapace) of artificially infected shrimp, the WSSV replication cycle has been estimated at $\sim 22 \mathrm{~h}$ [10]. In contrast, WSSV particles have been shown to interact with crayfish hemocytes. Thus, an earlier expression of Ser/Thr PK may indicate a higher susceptibility of hemocytes to be infected than cells of the cuticular epidermis. The issue of WSSV tissue tropism will be further analyzed.

Interestingly, it was recently reported that 12 of the 16 identified IE genes (wsv078, wsv079, wsv080, wsv083, wsv091, wsv094, wsv098, wsv099, wsv100, wsv101, wsv103, and wsv108) form a cluster in a $14.2 \mathrm{~kb}$ genomic region of the WSSV China isolate [58]. These genes may be transcribed from both DNA strands and therefore in opposite directions, such gene organization into a defined cluster could facilitate both its coordinated control and its rapid expression during early stages of infection.

Recently, studies on the crystal structure of VP9, a full-length WSSV protein encoded by ORF wsv230, revealed that VP9 may possess a DNA recognition fold with specific metal binding sites, similar to those of ferredoxin, with the ability to bind heavy metals as $\mathrm{Zn}^{2+}$ and $\mathrm{Cd}^{2+}$. It is worth mentioning, that this is the first WSSV protein structure to be reported. It is proposed that in the crystal, two dimers come together to form one asymmetric unit, which possesses a DNA recognition fold and specific metal binding sites. Even when the function of VP9 remains unknown, it has been suggested that VP9 might be involved in the transcriptional regulation of WSSV [75], as occurs in other viral proteins.

\subsubsection{Early viral genes}

The "life" cycle of viruses is characterized by the production of viral progeny, which must be supplied with a genome, making thus the DNA replication a critical and central event in the viral replication cycle. Thus, DNA polymerase plays a critical role in determining the level of genomic replication.

The WSSV genome comprises a DNA polymerase gene (dnapol) identified by the presence of three highly conserved motifs (Exo I, II, and III). Alignment of the WSSV dnapol with those 
of eukaryotes and other viruses showed that the seven motifs present on most DNA polymerases are also conserved on WSSV. However, it shows low overall homology (22-24\% identity) with other DNA polymerases, and when compared with those reported from eukaryotes and other viruses it is larger (2351 versus 913-1244 aa) [14]. The mapping of the dnapol sequence revealed a transcriptional start point located 24-27 nt upstream of the predicted ATG initiation codon, while a putative TATA box was found at $n t-52$ to -57 relative to the ATG translational start. The sequences surrounding the putative translation initiation codon (GAGATGA) conform reasonably well to the eukaryotic translation consensus sequence. Besides, the structure of the WSSV dnapol promoter (having an initiator sequence with a CAGT motif located $-25 \mathrm{nt}$ downstream of the TATA box) seems similar to that found in arthropod promoters responsive to RNA polymerase II [16]. Moreover, it is suggested that the A within the CAGT motif could be the major transcriptional start point. Thus, it is possible that, as in most of the insect baculovirus early genes having one or both of these basal elements, the WSSV dnapol transcription may be mediated by host RNA polymerase II [14].

From the several viral enzymes participating in nucleic acid metabolism, the activity of the ubiquitous enzyme dUTP pyrophosphatase (dUTPase) plays a pivotal role in the survival of the virus. This enzyme serves two major biological functions: (1) it maintains a low dUTP:dTTP ratio, thereby preventing misincorporation of uracil into DNA and consequently avoiding DNA breakage, and (2) it synthesises the substrate for thymidylate synthase in the biosynthesis of dTTP [112].

Laboratory studies revealed that the WSSV ORF wsv112 encodes a protein sharing some characteristics with dUTPases. The encoding gene, named wdut, consisting of $1383 \mathrm{nt}$, includes a putative translation codon (GCCATGG) and a putative TATA box located $100 \mathrm{nt}$ upstream of the predicted translation site. However, the sequence lacks a typical polyadenylation signal near the translation stop codon. When compared to other viral
dUTPases, five regions of the deduced amino acid sequence (461 aa) are highly conserved, and its arrangement resembles some recognised motifs of homotrimeric dUTPases. Interestingly, the whole WSSV dUTPase is two times larger than other known homotrimeric dUTPases (130-190 aa), a feature that has been observed in some other WSSV proteins, such as thymidine kinase [74, 126].

Ribonucleotide reductases (RR) are key enzymes in living cells since they catalyze the reduction of ribonucleotides to the four deoxyribonucleoside triphosphates (dNTP) required for DNA synthesis. A common feature of all RR is their ability to provide an appropriate balance of the four DNA building blocks. The Escherichia coli RR enzyme is considered as the prototype and functions as a heterodimer consisting of two large (RR1) and two small (RR2) subunits encoded by different genes. Analysis of a $12.3 \mathrm{~kb}$ segment of the WSSV genome revealed the presence of the genes encoding the large (RR1) and small (RR2) subunits of the RR, arranged in a head-to-head opposite configuration but separated from each other by $5.7 \mathrm{~kb}$ [125]. The RR1 ORF is composed of $2547 \mathrm{nt}$ (potentially encoding an 848 aa protein, with a theoretical molecular mass of $96 \mathrm{kDa}$ ), while the RR2 ORF is composed of $1242 \mathrm{nt}$ (potentially encoding a 413 aa protein, with a theoretical molecular mass of $47.6 \mathrm{kDa}$ ) [151]. Sequence analysis of the WSSV RR1 and RR2 genes showed that both $r r 1$ and $r r 2$ include transcription start sites at positions -84 and -68 , respectively, relative to the ATG translational start codon. In the same way, at the $3^{\prime}$ end of both $r r l$ and $r r 2$ ORF there are polyadenylation signals (AATAAA) 3-8 and 60-65 nt downstream of the translational stop codon, respectively. TATA boxes for WSSV $r r 1$ and $r r 2$ were identified at -103 to -108 and -99 to $-94 \mathrm{nt}$, respectively. Although some viruses contain two copies of the $r r 2$ gene, it was found that the WSSV $\mathrm{RR}$ is encoded only by a single copy of each gene [125]. Even when the WSSV $r r 1$ and $r r 2$ genes were identified and characterized $[125,130]$ it was necessary to establish if these genes were capable of encoding a fully functional enzyme. This may represent an advantage 
for WSSV due to the fact that viruses with their own RR are able to replicate in host non dividing cells in which RR are at very low levels. In this way, the two recombinant WSSV subunits RR1 and RR2 were separately expressed in a baculovirus/insect cell system, and the ability of WSSV recombinant RR1 and RR2 subunits to associate together in vitro to form a functional holoenzyme with the expected catalytic activity was demonstrated [69]. The synthesis of WSSV RR in WSSV-infected shrimp may explain the efficient replication of this virus not only in young/actively proliferating cells but also in old/resting cells.

Three more genes encoding enzymes related to DNA metabolism have been identified within the WSSV genome: thymidylate synthase (TS), thymidine kinase (TK) and thymidylate kinase (TMK). It is now recognized that WSSV ORF wsv067 encodes a TS protein with a molecular mass of $32.6 \mathrm{kDa}$. The TS gene includes a transcription start at $-22 \mathrm{nt}$ relative to the ATG translational start codon, a putative TATA box at $-28 \mathrm{nt}$ of the transcriptional initiation site, and a poly(A) tail $116 \mathrm{nt}$ downstream of the termination codon. However, no typical polyadenylation signal was found, indicating that other undefined signal regulating polyadenylations may exist [65]. Furhermore, it has been reported that both dUMP and folate attach to highly conserved TS binding sites to form a ternary complex during the catalytic reactions, causing a conformational change [6]. Similar spectra were detected when UV spectroscopic measurements were carried out on recombinant WSSV-TS activity, indicating thus that the TS encoded by ORF wsv067 is functionally active [65].

The WSSV genome contains a gene encoding a TK-TMK chimeric protein (WSSV $t k$-tmk, wsv395). In vitro transcription and translation of the WSSV tk-tmk ORF (1167 nt) was performed using the rabbit reticulocyte lysate system, yielding a major translation product with a size of $43 \mathrm{kDa}$, similar to the estimated size of the WSSV tk-tmk gene product. However, its catalytic activity was not measured [126]. Recently, the coding region of WSSV tk-tmk was expressed in an insect/baculovirus expression system, the recombinant product was purified and its enzymatic activity was measured. No TMK activity was detected, but the recombinant protein (rWSSV-TK-TMK) catalysed the phosphorylation of thymidine, indicating thus that the WSSV tk-tmk ORF (wsv395) encodes a functional TK [127]. RT-PCR analysis revealed the presence of transcripts of the tk-tmk transcript as early as $4 \mathrm{~h}$ p.i., and it continued to be found up to $60 \mathrm{~h}$ p.i. [126].

Two other WSSV early genes involved in replication and transcription have been reported: DNA helicase (wsv447) [54], and a homologous-region-binding protein (wsv021), however the comparative analysis of the putative protein sequences of these genes showed very weak similarities to known proteins $(<20-39 \%)$. Based on the panning of a phage library, WSV021 was found to bind specifically to a $210 \mathrm{bp}$ DNA sequence from the $\mathrm{b}$ minifragment of WSSV $h r 2$, suggesting that wsv021 might be a key functional gene involved in DNA replication and transcriptional regulation [173]. However, whether these WSSV ORF are translated into functional proteins remains to be elucidated. Furthermore, to date there are no reports of genes involved in transcription and mRNA biogenesis, which may therefore be absent in WSSV or its degree of amino acid homology may be too low when compared with similar proteins [133].

Several other genes have been reported as being expressed early after infection. Thus the wsv477 gene, an ORF of $624 \mathrm{bp}$ encoding a protein of 208 aa, contains a presumptive ATP/GTP-binding motif. Cloning and overexpression of the wsv477 gene yielded a GST fusion protein (GST-WSV477) exhibiting GTP binding activity. Protein motif analysis showed that the WSV477 protein had a typical ATP/ GTP-binding motif (P-loop), as most of the ATP/GTP-binding proteins. Based on these data, it was proposed that wsv477 might be an early regulatory protein of WSSV, which can be considered a remarkable finding since there are no reports of regulatory early genes for this virus to date [32]. A list of genes reported to date as early expressed after WSSV infection with primary references is compiled in Table III. 
Table III. WSSV early (E) expressed genes during infection.

\begin{tabular}{lcccc}
\hline Gene name & Putative function & Length (amino acids) & Gene expression (h p.i.) & Reference \\
\hline wsv001 & WSSV-clp (collagen-like protein) & 1684 & 4 & {$[61]$} \\
wsv021 & Homologous-region-binding protein & 306 & 4 & {$[173]$} \\
wsv067 & Thymidylate synthase & 289 & 4 & {$[65]$} \\
wsv112 & dUTPase & 461 & 4 & {$[74]$} \\
wsv143 & SOX transcription factor & 2313 & 2 & {$[64]$} \\
wsv172 & Ribonucleotide reductase 1 & 848 & 4 & {$[125]$} \\
wsv188 & Ribonucleotide reductase 2 & 413 & 6 & {$[125]$} \\
wsv395 & Thymidine kinase/thymidylate kinase & 398 & 4 & {$[126]$} \\
wsv447 & DNA helicase & 1936 & 6 & {$[54]$} \\
wsv477 & GTP-binding protein & 208 & 4 & {$[32]$} \\
wsv514 & DNA polymerase & 2351 & 6 & {$[14]$} \\
\hline
\end{tabular}

Despite increasing knowledge of the WSSV genome structure, promoters and regulatory sequences of the WSSV genes are largely unknown. Well known promoter elements used by many viruses are the TATA box and the initiator sequence, which is located at or near the transcription initiation site (TIS). Thus, a search for putative WSSV regulatory promoter elements was performed to compare the abundancy of all 4-8 nucleotide motifs, in the 100-200 nt upstream sequences of 8 WSSV early genes (protein kinase, DNA polymerase, thymidylate synthase, dUTPase, latency-related gene, large and small subunit of ribonucleotide reductase, and endonuclease) relative to their presence in the WSSV genome [86]. The consensus TATA box sequence (TATA(a/t)A) appeared relatively more frequently among these genes, than in the complete WSSV genome, while the TIS was identified located 20-30 nt downstream from the TATA box, therefore both elements may function synergistically. Both elements are located 20-85 nt upstream of the translational start codon of the early gene products. When the early gene sequences were aligned by maximizing the identities around the transcriptional start site, a clear consensus transcription initiation motif $((\mathrm{a} / \mathrm{c})$ TCANT $)$ overlapping with the transcriptional start sites was identified. The identification of the TATA box, the TIS and a conserved transcription initiation motif in the studied WSSV early genes suggests that WSSV is capable of using the host RNA polymerase transcription machinery for generating early transcripts, which has been proposed previously $[14,74]$.

\subsubsection{Viral late genes}

Although the existence of IE, E and L WSSV expressed genes has been recognized, the mechanism permitting to switch between this different co-regulated classes of genes remains unknown [86]. However, some preliminary molecular events underlying this shift are starting to be understood.

To date several WSSV late genes have been identified, and are summarized in Table IV. Recent experimental evidence indicates that $65.6 \%$ of the 532 putative genes isolated in gills of experimentally infected $P$. monodon were expressed after $12 \mathrm{~h}$ p.i. [141]. The structural protein WSV010, was identified for the first time as a novel structural protein by means of a shotgun proteomic approach [12, 64]. Recently, experimental evidence strongly supports that WSV010 associates with VP24 either directly or indirectly, which allows WSV010 to anchor to the envelope [12]. Previous work showed that VP24 could also interact with the structural proteins VP28 and VP26, forming a stable protein complex that plays a role in virus infection [163]. Thus, it is suggested that VP24 may act as a linker between the structural proteins VP28, VP26, WSV010, and probably other envelope proteins, to form a complex on the viral envelope, although such a protein complex has not yet been detected in vivo. 
Table IV. WSSV late (L) expressed genes during infection.

\begin{tabular}{lcccc}
\hline Gene name & Putative function & Length (amino acids) & Gene expression (h p.i.) & Reference \\
\hline wsv002 & VP24/Structure protein & 208 & 18 & {$[39]$} \\
wsv009 & VP95/Structure protein & 95 & 18 & {$[39]$} \\
wsv010 & WSSV010/Structure protein & 97 & 24 & {$[12]$} \\
wsv311 & VP26/Structure protein & 204 & 18 & {$[39]$} \\
wsv191 & Non-specific nuclease & 304 & 8 & {$[59]$} \\
wsv214 & VP15/Structure protein & 80 & 16 & a \\
wsv216 & VP124/Structure protein & 1194 & 24 & {$[172]$} \\
wsv230 & Icp11 & 82 & 18 & {$[142]$} \\
wsv308 & VP466/Structure protein & 466 & 18 & {$[39]$} \\
wsv340 & VP31/Structure protein & 261 & 12 & {$[60]$} \\
wsv339 & VP39/Structure protein & 283 & 12 & {$[174]$} \\
wsv414 & VP19/Structure protein & 121 & 24 & {$[86]$} \\
wsv421 & VP28/Structure protein & 204 & 6 & {$[170]$} \\
wsv427 & Latency-related gene & 623 & 6 & {$[81]$} \\
\hline
\end{tabular}

${ }^{a}$ See footnote 2.

Up to date, at least 19 proteins have been confirmed as components of the WSSV envelope and these proteins may play important roles in virus binding, entry, and assembly. Analysis of the deduced protein sequence VP466 reveals a transmembrane $\alpha$-helix formed by the amino acid residues 338-358, which has been considered to play a role in mediating the movement of this protein into the nuclear membrane and subsequently assembled as viral enveloped within the nucleoplasm [39]. In a similar way, bioinformatic analysis has shown that the $v p 76$ gene encodes a protein containing a putative conserved motif sequence of a class I cytokine receptor, several glycosylation sites and a signal peptide, but not a transmembranal domain [42]. Transcriptional analysis showed that $v p 76$ was transcribed at $24 \mathrm{~h}$ p.i., which is in agreement with previous results [43], but detected later when compared with other reports [124]. Such a difference may be caused by the use of an inoculum suspension with a lower virus copy number or because of the use of different crustacean species. Another gene, vp31, was predicted to encode an envelope protein which lacks a predominant transmembrane domain, indicating that it may function as a fusion protein containing a domain involved in binding to other viral envelope proteins for membrane anchoring [60], however, this conclusion still needs more acute substantiation. Furthermore, the analysis of the temporal expression of the structural WSSV protein genes $v p 28, v p 26, v p 24, v p 19$ and $v p 15$, during infection was studied in experimentally infected crayfish (O. limosus) and shrimp (P. mono$d o n)^{2}$. It was found that transcripts of $v p 15$ were first detected from $16 \mathrm{~h}$ p.i., while transcripts of $v p 19, v p 24, v p 26$, and $v p 28$ were detected from 1 day p.i., onwards. It was evident that the expression of $v p 24$ was the lowest of the major structural protein genes analyzed, which is in agreement with previous studies describing that the WSSV virion particles contain only minute amounts of the VP24 protein [134]. No significant differences were detected in temporal transcription of the WSSV major structural protein genes between $O$. limosus and P. monodon ${ }^{2}$. Finally, it has been reported that the WSSV structural protein VP664 is expressed in late stages of infection [86]. Interestingly, other studies found that small amounts of vp664 transcripts were detected as early as $2 \mathrm{~h}$ p.i., and

\footnotetext{
${ }^{2}$ Marks H., Genomics and transcriptomics of white spot syndrome virus, Ph.D. thesis, Department of Plant Sciences, Wageningen University, The Netherlands, 2005.
} 
that the expression level remained constant until $8 \mathrm{~h}$ p.i., and subsequently, the amount of vp664 transcript increased significantly from $12 \mathrm{~h}$ p.i., until the end of the study, for this reason it is considered as a late expressed gene [56].

Nucleases are among some of the most interesting late genes identified in the WSSV genome. Analysis of the WSSV genome revealed the presence of a $936 \mathrm{nt}$ ORF (wsv191) with high homology to prokaryotic and eukaryotic endonucleases. Bioinformatic analysis of the putative protein encoded by this ORF (311 aa) suggested that it must include a nonspecific endonuclease motif. Besides, the protein contains most of the structurally and functionally significant amino acid residues identified in nucleases from several organisms [152]. Functional characterization of the 5 -flanking region of the non-specific nuclease gene revealed that the TIS is located at $19 \mathrm{nt}$ downstream of a typical TATA box, while analysis of the 3 -end sequence identified a poly(A) tail located at $17 \mathrm{nt}$ downstream of a typical polyadenilation signal (AATAAA). Recombinant WSSV nuclease protein (termed rWSSVNSN) was capable to hydrolyze both DNA and RNA, indicating that wsv191 is a genuine non-specific nuclease gene [59].

Finally, in addition to the major structural proteins, the protein profile of WSSV particles shows a range of about 40 minor proteins, most of which are supposed to be expressed during the late phase of infection. More recent work has shown that 18 of the 40 WSSV putative late genes analysed contain a consensus TATA box within $300 \mathrm{nt}$ of the translational start codon, which may suggest that WSSV also exploits the cellular RNA polymerase II system, at least for some part of its late mRNA synthesis [86]. Besides, amongst the 8 major structural virion protein genes that are expressed in the late phase of viral infection and most likely are co-regulated to secure correct assembly of the virion, only $v p 15$ contains a consensus TATA box at a functional distance of the TIS. Alignment of the $5^{\prime}$ ends of the 8 major structural protein genes identified a novel consensus TIS, ATNAC, located 20-25 nt downstream of an $\mathrm{A} / \mathrm{T}$ rich region. Bioinformatic analysis of these elements suggests that both components might be late promoter elements. This resembles a process used by baculoviruses to transcribe its genes during the late stages of replication, which is based on the usage of a DNAdirected RNA polymerase that binds to compact late viral gene promoter elements with different characteristics from $\mathrm{E}$ genes and cellular promoters [93]. However, contrasting with baculoviruses, the WSSV genes required to take full advantage of this process, such as a RNA polymerase or late transcription factors, have not been identified yet on the WSSV genome. These genes could have diverged greatly from known homologue sequences to be found in the basis of its amino acid homology [86].

\subsection{Latency-related genes}

Despite its high prevalence in natural populations, viral strategies for persistence have not received much attention. Persistence has been defined as the state in which a virus maintains its capacity for either continued or episodic reproduction in an individual host, subsequent to an initial period of productive infection and occurrence of an antiviral host response. This definition also includes the condition known as latency in which virus reproduction can be partially or completely suppressed for prolonged periods, but the capacity for reactivation is maintained. Recently, specific-pathogen free (SPF) shrimp, selectively bred for six generations in a controlled environment, and analyzed with a standard commercial test for the absence of WSSV, were developed and commercialized. Some of these organisms, however, displayed a number of symptoms resembling those of WSSV infection, which could be caused by the reactivation of latent WSSV infection triggered by environmental stress. Thus, by using a DNA microarray analysis, exceptionally high signal intensities from some elements on the array (ORF 151, 366 and 427) were detected, indicating that these shrimp had been carriers of the virus and were actively expressing viral genes. The analysis of the deduced protein structure of each of the WSSV gene sequences revealed some putative motifs that may contribute to modulating host and/or viral transcription 
via protein-DNA interaction, including a $\mathrm{Myc}$ type helix-loop-helix dimerization domain signature, a leucine zipper motif, an $\mathrm{EF}$ hand $\mathrm{Ca}^{2}$-binding domain, a homeobox domain, and Nt-DnaJ domain signature, among the three genes [51]. It is now accepted that virus latency depends on interactions between several factors including the host's immune system, viral gene regulation, and cell factors, and that several genes are recognized to participate in the process. Further characterization of ORF89 showed that it is transcribed into an unspliced mRNA of $4436 \mathrm{nt}$, which encodes a nuclear protein of 1437 aa, including a NLS situated near the center of the polypeptide, among the amino acids ${ }^{678} \mathrm{KMKRKR}^{683}$, responsible for locating the protein in the cell nucleus. Cotransfection assays demonstrated that ORF89 protein repressed its own promoter as well as those of the PK and TMK genes of WSSV, which may suggest that ORF89 contributes to establishing viral latency by repressing PK and TMK, but this still needs to be demonstrated [115]. More recently, interactions between the ORF427 protein and a novel shrimp serine/threonine protein phosphatase (PP) were found [80], suggesting that shrimp PP may be involved in the latent-lytic life cycle of WSSV through interacting with ORF427. Similar results have been reported in other studies in which transcripts of the WSSV ORF403 were detected in SPF shrimp, indicating that this gene may also be involved in virus latency [38]. In addition, it was found that the WSSV403 protein is able to interact with a shrimp PP, which has previously been reported to interact with WSSV427, but the relation, if any, between WSSV403, WSSV407 and shrimp PP is not yet understood.

\subsection{Anti-apoptosis genes}

There is still scarce information concerning the mechanisms of shrimp involved in response to viral pathogens. However, it has been reported that WSSV may force shrimp cells into a state of apoptosis, since some signs of apoptosis have been identified [106, 155]. This process of cellular self-destruction can serve to eliminate cells that might prove harmful to the organism. However, viruses have selectively fixed strategies to evade such immune control. At present, the factors that can trigger apoptosis are currently unknown, although an anti-apoptosis protein (ORF390) was recently identified in WSSV [149]. Two separate series of experiments were carried out: in the first experiment a primary shrimp cell culture of lymphoid organs infected with WSSV was treated with actinomycin D. Actinomycin blocks protein cell synthesis, and induces apoptosis in many kinds of cells. Thus, cells infected with WSSV did not show obvious characteristics of apoptosis, while those only treated with actinomycin reduced their number and its DNA was degraded into a ladder-like pattern typical of apoptotic cells. In the second set of experiments, an insect cell line was infected with AcMNPV $\Delta 35 \mathrm{k} / \mathrm{pol}+$ (an inhibitor of proteases involved in apoptosis). The insect cells were co-transfected with a recombinant plasmid containing ORF390. Thus, the transfected cells prevented some characteristic morphological changes occurring in nuclei during apoptosis. Furthermore, it was suggested that ORF390 may block apoptosis directly by a mechanism that does not require any other virus-encoded apoptosis regulator during WSSV infection [149]. The latest findings indicate that ORF390, which contains a predicted caspase3 cleavage site among the amino acids ${ }^{269} \mathrm{DEVDG}^{273}$, is cleaved by a novel shrimp caspase, and subsequently the cleaved protein fragment directly binds to the caspase, thus blocking its apoptotic activity [57]. In this way, apoptosis inhibition by ORF390, may create a suitable environment for the virus, driving to a competitive advantage against the host for replication components. Furthermore, it has been reported that the cumulative mortality of low-dose WSSV-challenged organisms, injected with dsRNA directed against the cap-3 gene was significantly reduced, supporting the hypothesis that apoptosis affects shrimp negatively by increasing mortality after viral challenge [101].

Gene $w s v 249$ encodes a protein (WSV249) containing a predicted RING-H2 domain [58]. RING finger domains are the largest class of E3 ubiquitin ligases that are involved in cell 
cycle control, apoptosis and viral replication control. Biochemical analysis showed that WSV249 physically interacts with a shrimp ubiquitin E2 enzyme, PvUbc, acting as ubiquitin E3 ligase to mediate the in vitro ubiquitination through its RING-H2 motif in the presence of ubiquitin E1 and PvUbc [150]. Three other WSSV proteins have been predicted to contain RING-H2-domains: WSV199, WSV222 and WSV403. Since WSSV infection may result in apoptosis in shrimp cells, it is now clear that upon interaction with WSV222, a shrimp protein that induces apoptosis (TSL, tumor suppressor-like) is ubiquinated and subsequently degraded via the $26 \mathrm{~S}$ proteasome. Thus, WSV222 is strategically used by WSSV to inhibit apoptosis, thus ensuring its replication and survival [37].

\section{4. icp11: the most highly expressed gene of WSSV}

It seems obvious that viral fitness (a parameter defining the ability to produce infectious progeny) is determined by the expression of genes encoding proteins involved in fundamental processes, such as virus structure, virus replication, or evasion of host immune defense mechanisms, which may ensure viral survival in a hostile environment. Thus, high expression levels of a viral gene/protein may in part reflect its functional and adaptive significance.

Recently, it was found that the WSSV gene icp11 (also identified as $v p 9$ ) is the most highly expressed viral gene at both transcriptional and translational levels (it was 3.5-fold more highly expressed than the major envelope protein gene $v p 28$ ). Its encoded protein, ICP11, is a nonstructural protein localised in both cytoplasmic and nuclear compartments [142], and contains a fold and a negative charge comparable with those recognised in dsDNA, suggesting that it may function by mimicking the DNA shape and chemical character [143]. Furthermore, it was found that ICP11 binds directly to the DNA binding site of nucleosome-forming histones (H3 and H2A.x), interfering, thus, with critical functions of DNA damage repair, and nucleosome assembly, which has been reported as a mechanism to manipulate cellular chromatin to ensure viral genome survival and propagation.

\section{VIRULENCE}

It is not an easy task to define virulence; however, as defined by evolutionary biologists, it is the reduction in host fitness attributable to a pathogenic infection [4]. Thus, several similarities have been found among several WSSV isolates, including morphology and proteomes. Similarly, preliminary studies indicated minor differences in virulence between WSSV isolates, although direct comparisons were not made [53]. Further studies compared the virulence of six geographic isolates of WSSV (WSSV-Cn, WSSV-In, WSSV-Th, WSSVTexas, WSSV-South Carolina and from infected crayfish maintained at the USA National Zoo) in two different Penaeid species (P. vannamei postlarvae, and $F$. duorarum, juveniles) inoculated orally. All six WSSV isolates caused severe mortalities $(100 \%)$ after challenge in $P$. vannamei postlarvae, with the WSSV-Tx isolate which caused mortalities more rapidly, while the crayfish isolate caused slower mortalities. In contrast, mortalities caused by WSSV-Tx in juveniles of $F$. duorarum reached $60 \%$, while mortalities with the crayfish isolate reached only $35 \%$ [148]. Furthermore, a comparative study between the isolate containing the largest genome identified at present, WSSV-Th-96-II (considered as the common ancestor of all WSSV isolates described to date) and WSSV-Th, the smallest genome identified so far, was carried out. The median lethal time $\left(\mathrm{LT}_{50}\right)$ upon exposure of $P$. monodon, via intramuscular injection, to the WSSV-Th-96-II inocula was significantly longer (14 days) when compared with that observed after exposure to WSSV-Th (3.5 days). When both isolates were mixed in equal amounts and serially passaged in shrimp, WSSV-Th outcompeted WSSV-Th96-II within four passages. In fact, only the genotype of WSSV-Th was detected in the DNA isolated after passage 5, which suggested the presence of a single isolate, WSSV-Th, and not isolate WSSV-Th-96-II or a recombinant form of WSSV genotype consisting of a mosaic 
of WSSV-Th and WSSV-Th-96-II. These data suggest a higher virulence of WSSV-Th compared to WSSV-Th-96-II, a competitive fitness depending on the size of the genome. Thus, a smaller genome may give an increase in viral fitness by faster replication [84].

\section{TISSUE TROPISM}

The success of any viral infection (successful replication) is mainly determined by the interaction between the viral attachment proteins (VAP) and the host's specific cellular receptors. As previously mentioned, WSSV can infect a wide range of crustacean and non-crustacean hosts, suggesting that WSSV has a VAP (several proteins contain a cell attachment signature) that can bind to common targets on different cells in a variety of hosts [66]. Until today, it has been widely accepted that after infection, WSSV can replicate in all the vital organs of Penaeid shrimp [121]. However, tissue or cell tropism results from highly specific interactions between a virus and the cell type it infects, which implies that viruses are not capable of infecting all types of cells indiscriminately. More recently, it was reported that WSSV infects mainly cells in tissues of ectodermal and mesodermal origins [156], while tissues of endodermal origin are refractory to WSSV infection [148]. However, orally WSSV-infected shrimp showed that once the virus has crossed the basal membrane of the digestive tract, virions are present, at different stages of morphogenesis, in the nucleus of circulating hemocytes, suggesting that viral replication must be occurring in this type of cells. Thus, hemocytes carrying virions are dispersed in the hemocoel through hemolymph circulation and are rapidly distributed in different tissues [21]. Since shrimp, as all Arthropods, possess an open circulatory system it is not surprising that the hemocytes are also found in other tissues, which may explain why WSSV has been detected in several tissues. Furthermore, a significant decline in the number of circulating hemocytes, or an increase in the number of apoptotic hemocytes after WSSV infection has been reported [111]. This may be caused by infection of the hemocytes or by an apoptotic event in the WSSV infected hematopoetic tissue. Among the different types of hemocytes found in shrimp, semigranular cells (SGC), which comprise $\sim 58 \%$ of the hemocytes, were more vulnerable to be infected by WSSV than granular cells (prevalence of $22 \%$ and $5 \%$, respectively). An interesting observation was that granular cells from non-infected crayfish exhibited melanisation when incubated in L-15 medium, while no melanisation was observed in granular cells from infected organisms, which may suggest that WSSV is capable of inhibiting the prophenoloxidase system upstream of phenoloxidase (which may play a role against WSSV), or that this virus somehow consumes the substrate of the enzyme so that no activity is detected [47]. Finally, it seems feasible that WSSV infect specific cell types in hematopoietic tissue, of which semigranular cells seem more prone to be infected.

\section{STRATEGIES FOR THE CONTROL OF WSSV}

Due to the impact that WSSV has caused to shrimp cultures all over the world, several approaches have been used for the management of the disease. A brief summary of the state-ofthe-art of the main strategies followed to control WSSV infection will be given. However, it is worth noting that at present there is no treatment available to interfere with the unrestrained occurrence and spread of the disease, while rigorous sanitation practices on shrimp farms have produced relatively good results.

\subsection{Shrimp antiWSSV immune response}

Crustaceans lack a true adaptive immune system and rely on innate immune response to recognize and destroy non-self materia. Hemocytes are an important part of the defense system employed by Crustaceans against pathogens, since they initiate coagulation, a mechanism that prevents dissemination of invading microorganisms around the body. The antiviral activity of hemocyanin as an important innate immune response against WSSV has been 
previously reported, since it is capable to delay WSSV infection, inhibiting viral replication. In fact, a hemocyanin subunit $(\mathrm{PjHcL})$ seems to be more sensitive to WSSV infection, than other subunits, since transcripts of this gene in WSSV-infected organisms were significantly higher than those of other subunits. However, the precise mechanism of action of hemocyanin remains to be determined [55].

Other mechanisms have been proposed to participate in shrimp defense functions against WSSV. Thus, it was suggested that an antiviral gene (PmAV) from $P$. monodon encodes a protein with a C-type lectin-like domain (CTDL). The recombinant protein inhibited virus induced cytopathic effects in cultured fish cells, but it was not mediated via agglutination, which may suggest that $P m A V$ does not encode a lectin. Furthermore, it was found that $P m A V$ mRNA was up-regulated in virus-resistant shrimp, indicating that this gene is inducible providing a mechanism to assure a precise control of its expression according to the circumstances [82].

Similarly, another shrimp gene was found to be highly homologous with Ras-related nuclear proteins (Ran), which are capable of regulating multiple processes related to structure assembly, suggesting that the shrimp Ran protein may participate in the regulation of the host defense against virus and other microorganisms [92]. It was also proposed that this gene may be involved in the antiviral response of artificially infected shrimp as it was up-regulated at 4 h p.i. [33].

Furthermore, it was found that the protein PmRab7from P. monodon interacts directly with the major WSSV envelope protein VP28. In vivo neutralization assays showed that the cumulative mortality of shrimp injected with WSSV plus PmRab7 was significantly lower $(15 \%)$ when compared with that of organisms challenged only with WSSV (95\%) [118]. It was subsequently found that a Rab GTPase gene was up-regulated in virus-resistant shrimp [160]. Thus, it was proposed that the protein encoded by this gene is capable of detecting virus by forming a protein complex between Rab GTPase, actin, tropomyosin, and the WSSV envelope protein VP466, and then the
Rab GTPase triggers the shrimp antiviral hemocytic phagocytosis [161].

Recently, a focal adhesion kinase (FAK), a cytoplasmic protein-tyrosine kinase involved in integrin-mediated signal transduction that can be activated upon adhesion of cells to the extracellular matrix such as fibronectin, was reported in the shrimp $P$. japonicus (MjFAK). In early stages of WSSV experimentally infected organisms, the amount of MjFAK protein increases significantly, which may imply that the virus is capable of using the interaction between viral RGD-containing proteins and surface integrin, leading to the $\mathrm{MjFAK} /$ phosphorylation up regulation, which in turn facilitates the entry of virus and the delivery of its genome into the host nucleus. From a host perspective, cell adhesion in invertebrates is essential to the cellular immune responses of encapsulation and nodule formation. Thus, during a WSSV infection, especially in the early stage, the MjFAK expression/phosphorylation increases to promote cell adhesion. In order to thwart this negative consequence, virus downregulates MjFAK expression, which significantly reduces its hemocyte adhesion activity. This means that WSSV accomplishes its infection by activating MjFAK; while the host simultaneously produces a protective effect against viral infection by increasing cell adhesion. These results suggest that MjFAK may integrate signals from virus pathogen stimuli into different cellular outcomes via distinct downstream pathway [168]. However, the mechanism of MjFAK activation and cell adhesion enhancement is still unclear.

\subsection{Environmental control of WSSV}

As it often happens in aquaculture, the information generated by different sources may at times be contradictory and confusing. Thus, during a WSSV epizootic event occurring in China in 1998, mass mortalities were attributed to elevated water temperature. On the contary, shrimp farmers observed a significant increase in the severity of WSSV due to low water temperatures. A general observation is that serious WSSV epizootics are less probable to occur during warm periods, and it has been proposed 
that management practices that increase pond temperature may offer an interesting opportunity to manage this disease [138]. In addition, it has been reported that low temperatures may help shrimp to gain protection against WSSV, probably by reducing viral replication [30]. Thus, no mortality was observed in the freshwater crayfish $P$. leniusculus experimentally infected with WSSV at 4 and $12{ }^{\circ} \mathrm{C}$, while those organisms at higher temperature $\left(22{ }^{\circ} \mathrm{C}\right)$ reached $100 \%$ mortalities at 12 days p.i. Interestingly, WSSV-infected organisms were kept at $22{ }^{\circ} \mathrm{C}$ during 5 days, and then held at 22 , 16 and $12{ }^{\circ} \mathrm{C}$. The mortality of WSSV-infected crayfish at $22{ }^{\circ} \mathrm{C}$ was up to $100 \%$ within 3 days, while WSSV-infected organisms at 16 and $12{ }^{\circ} \mathrm{C}$ reached $100 \%$ mortalities within 20 and 35 days, respectively, after transfer from $22{ }^{\circ} \mathrm{C}$. These results suggest that WSSV may enter the target cells and replicate at high temperatures, while low temperatures may decrease this effect, probably because the virus only attaches to the cell surface without replication [46].

Finally, an increase in water temperature from 27 to $33{ }^{\circ} \mathrm{C}$ showed two opposite effects in WSSV-infected shrimp ( $P$. vannamei) depending on the stage of infection. In an acute stage of infection, the increase in water temperature significantly decreased mortality, probably by inhibiting virus replication. However, in a chronic stage of infection, the increment of water temperature caused a rapid progression of disease and mortality in WSSV-infected shrimp [96].

Despite the still scarce existing information, it is hardly expected that WSSV could be controlled just by changes in the pond temperature. However, such temperature changes may give some time to the shrimp farmer to manage an emergency harvest.

\subsection{Pre-exposure to shrimp pathogens}

It is widely accepted that viruses are capable of inhibiting both cellular macromolecular synthesis and the replication of co-infecting heterologous or homologous viruses, a phenomenon termed as viral interference. Inhibition of replication may be caused by several mechanisms, which include the blockage of virus entry by down-regulating viral receptors, the competition between viruses for a common receptor, the inhibition of the host's cell functions required by the co-infecting virus, or by the blockage of virus transcription. In crustaceans, it is also possible that viruses may block replication of a second virus by activation of an innate immune response, by which anti-viral factors may be released into hemolymph [3].

Thus, some studies have indicated the protection against WSSV conferred by a preinfection with the infectious hypodermal and hematopoietic necrosis virus (IHHNV) in $P$. stylirostris and P. vannamei $[3,87]$. Accordingly, mortalities of IHHNV pre-infected shrimp, after oral exposure to WSSV-infected tissues, were significantly diminished or delayed. A common denominator of these studies was that the surviving shrimp showed higher IHHNV loads when compared to the WSSV load. However, the molecular and cellular mechanisms underlying the interference process remain to be elucidated.

It has been traditionally accepted that the use of probiotics may help to enhance shrimp health by preventing colonization of pathogens and inducing responses of the immune system. Another proposed alternative to enhance the shrimp immune system is the usage of $\beta-1,3 /$ 1,6-glucans. Thus, postlarval and juveniles of $P$. monodon were fed with experimental diets containing $\beta$-1,3-glucan, and challenged with WSSV. None of the control organisms (fed with experimental diets without $\beta$-1,3-glucan) survived beyond 4 days, while the organisms fed with glucan significantly increased its survival rates up to 120 days [8]. Thus, the results of this investigation do not demonstrate a conclusive link between probiotics/immune enhancers and resistance of shrimp against WSSV infection.

\subsection{Herbal treatments against WSSV}

Control of viral infections can be achieved by prophylactic (protective) or therapeutic measures. In this context, there is a growing interest in natural products capable of stimulating the immune system to prevent viral infections. 
Many traditional medicinal plants have been reported to have strong antiviral activity and some of them have already been used to treat virus infected animals (including shrimp).

Nevertheless, few attempts using plant extracts to confer protection to shrimp against WSSV infection have been published. In a recent study, methanol extracts of five Indian plants (Cynodon dactylon, Aegle marmelos, Tinospora cordifolia, Picrorhiza kurooa and Eclipta alba) were equally incorporated into experimental shrimp feed, and subsequently used to experimentally feed (injected) WSSVinfected shrimp. After 20 days, the survival of organisms provided with the diets containing the plant extracts showed significantly higher survival than those organisms supplied with diets devoid of the extract [19]. In a screening study on antiviral activity against WSSV, 20 Indian medicinal plants were tested, of which five plant extracts (A. marmelos, C. dactylon, Lantana camara, Momordica charantia and Phyllanthus amarus) showed antiviral activity. The aqueous extract of $C$. dactylon showed the strongest activity against WSSV since no mortality was observed until the end of the experiment at the 30th day p.i. [1]. Finally, the antiviral activity of the Indian plant Pongamia pinnata against WSSV was reported and survival rates of up to $80 \%$ were reached after 15 days p.i., while control shrimp showed a $0 \%$ survival after 6 days p.i. Furthermore, three major chromatographic fractions were obtained from ethanolic extracts of $P$. pinnata leaves. Such fractions were incorporated into a complete formulated feed and experimentally WSSV challenged shrimp were fed with these meals and the second fraction showed up to $50 \%$ survival of WSSV-infected shrimp compared to fractions 1 and 3. Spectral analysis of fraction 2 identified the antiviral compound as bis(2-methylheptyl)phthalate [100]. This compound has been identified in other plants, but it has not been previously reported as an antiviral agent.

It is worth pointing out that a common denominator of the above-mentioned control strategies is that they all require a wider scientific validation, since conclusive experimental evidence of its functionality to protect the shrimp against WSSV, still needs to be obtained. In addition, these strategies still remain to be validated as efficient, cost-effective and practical in production systems, since their application still seems premature due to the lack of understanding of the molecular mechanism of inhibition of WSSV replication.

\subsection{Vaccination trials to protect shrimp against WSSV}

The scientific literature concerning the immune system of crustaceans is abundant. It is widely accepted that crustaceans, as most invertebrates, lack a true adaptive immune response system and its defense against pathogens relies on various innate immune mechanisms, including both cellular and humoral responses. Thus, the development of a vaccine against WSSV, or other shrimp pathogens, has been severely impeded by such lack of memory-type immunity and by the lack of a comprehensive knowledge about the etiology of the disease. However, the presence of a quasiimmune response against WSSV was detected in the shrimp P. japonicus. Survivors of a WSSV outbreak were re-challenged after 4 months of the devastating event. A relative survival of $94 \%$ was reached on the WSSV survivors, which suggests that the resistance of organisms previously infected with WSSV was due to the enhancement of an immune-like system (quasi-immune response) [137]. Further studies implied that the resistance developed by surviving organisms against WSSV is due to an unknown WSSV neutralizing factor component of the shrimp plasma [159], suggesting that some adaptive immune response could exist in shrimp. However, the nature of such factors remains to be investigated.

More recently, several studies have begun to use recombinant WSSV envelope proteins to induce resistance in shrimp. $P$. japonicus vaccinated by injection with rVP26 once showed significantly higher resistance to WSSV, while organisms vaccinated twice with $\mathrm{rVP} 28$ at a 20 day interval, showed reduced mortalities to $4 \%$ [89]. The protective response was effective at 10 days post-vaccination (d p.v.), but not $30 \mathrm{~d}$ p.v., which suggests that mechanisms 
involved in this response may be different than those observed when organisms survive after exposure to infective WSSV. Similarly, lower cumulative mortalities were observed in $P$. monodon by oral or intramuscular vaccination with rVP28, rVP19 [154], and rVP292 [136].

Some of the results obtained in the above mentioned studies suggest the existence of an adaptive secondary immune response in invertebrates, homologous to that observed in vertebrates [159]. This topic has been deeply discussed, and it has been emphasized that the information of such phenomenological observations is still insufficient to support the case of adaptive immunity in invertebrates. Thus, such observations cannot be used in isolation and should not be used solely as the basis for radical claims contrary to well-established knowledge of innate immunity. They can, of course, be used to propose hypotheses that must be scientifically supported and exhaustively tested. Besides, it must be established if immune mechanisms found in invertebrates are homologous to those in vertebrates, since functional similarity in the immune system does not prove homology [36].

Finally, oral vaccination of shrimp against WSSV seems to be a very promising control strategy. However, adequate laboratory and field studies must be done prior to the release of a potential WSSV vaccine, which would require several years of research, making such vaccines unlikely to be available for commercial use in the near future.

\subsection{Nucleic acid-based vaccines as a novel approach against WSSV}

Although the usage of nucleic acid-based vaccines may be considered a novel strategy to reduce viral infections, this technology was first explored in the early 1990s. Now, it is accepted that the transfer of DNA or RNA to somatic cells may contribute to influencing the immune system of the organism, and these new kinds of vaccines have already been applied to prevent a wide range of infectious and malignant diseases.

\subsubsection{RNA-based vaccines}

Double-stranded RNA (dsRNA) is a well documented elicitor of the host response to viral infection, as it can trigger several intracellular and extracellular antiviral responses that alter the program of a cell. In vertebrates, dsRNA is a potent inducer of the protective type 1 interferon (IFN), requiring at least a single molecule of dsRNA to induce IFN synthesis. In contrast, IFN-like genes or proteins have not been found in crustaceans or arthropods yet, and thus it has been predicted that invertebrates lack the ability to mount antiviral responses (other than RNAi) when challenged with dsRNA [103].

Recent studies have reported that the injection of dsRNA in shrimp may induce a general antiviral response regardless of its sequence. Interestingly, there is evidence of significant reductions in cumulative mortalities in the shrimp $P$. vannamei previously injected with dsRNA transcribed from the gene for the duck (A. platyrhynchos) Ig $v$ heavy chain and experimentally infected with Taura Syndrome Virus (TSV) or WSSV [104]. Since this sequence has no similarity to any known shrimp gene or to the reported genomes of WSSV or TSV, it was suggested that such antiviral response may represent a more general mechanism against two unrelated viruses. Furthermore, WSSV-infected shrimp injected with dsRNA for VP19 showed a much higher pathogenspecific protection, when compared with those injected with randomly generated dsRNA, suggesting that shrimp can use pathogen-specific RNAi systems to generate targeted protection against viral diseases [102]. Similar results have been observed by intramuscular injection of dsRNA corresponding to VP28 and VP281 in $P$. chinensis, indicating that dsRNA-mediated protection is a common feature across shrimp species [52]. Moreover, the injection of short interfering RNA (siRNA, $19 \mathrm{bp}$ ) failed to induce a similar response, which implies a minimum size requirement for extracellular dsRNA to engage antiviral mechanisms and gene silencing [102].

Other studies suggest that the oral administration of bacterially expressed VP28dsRNA 
could become a therapeutic agent against WSSV as dsRNA treated shrimp challenged with WSSV showed higher survival rates $(68 \%)$ when compared to organisms vaccinated with feeds coated with inactivated bacteria containing an empty vector [114]. Thus, VP28dsRNA may act by silencing the expression of the wsv002 gene, as a decline of its transcripts was detected [113].

Similarly, WSSV replication was inhibited when dsRNA of Rab7 (a WSSV-VP28 binding protein) was injected into shrimp before challenge with WSSV. The Rab7 dsRNA-mediated gene silencing occurred $48 \mathrm{~h}$ after injection, which reduced the VP2 8 mRNA levels and virus protein expression. Thus, Rab7 may function in the endosomal trafficking pathway, and its silencing prevents the viral trafficking necessary for replication [90].

Finally, recent studies suggest that siRNA could suppress the gene expression and replication of WSSV. Thus, shrimp injected with VP15 or VP28 siRNAs, before a WSSV challenge, gave significantly lower mortality rates, but not different than those shrimp injected with green fluorescent protein (gfp) siRNA, which implyes that siRNA may induce a sequenceindependent antiviral response in shrimp [151]. On the contrary, experimentally WSSV-infected shrimp $P$. japonicus injected with a specific 21 bp short interfering RNA (vp28-siRNA) targeting the vp28 gene of WSSV showed lower mortalities than control organisms. When treated with vp28-siRNA, the expression of vp28 gene and the replication of viral DNA were significantly delayed or inhibited, indicating a sequence-specific response [164].

\subsubsection{DNA-based vaccines}

Vaccines are considered as one of the more effective methods to overcome viral infections. However, a number of viral diseases have not yet been eradicated by vaccines. An important impediment for a successful development of vaccines against such pathogenic agents is that they require a cellular immune response for protection, thus only those vaccines derived from attenuated organisms are capable of inducing an efficient response. However, the live use of a number of viruses is considered a safety risk. Besides, the protection conferred by vaccines to invertebrates has been found to yield short-term benefits. Alternatively, the potential of DNAbased vaccines against viral diseases in aquaculture has proven to be effective to reach a sustainable production.

Recent studies have reported the protection conferred (for up to 50 days) to experimentally WSSV-infected shrimp $P$. monodon injected with recombinant DNA plasmids encoding the envelope proteins VP28 or VP281, while the injection of DNA expressing the WSSV nucleocapsid proteins VP15 and VP35 did not elicit a protective response. Besides, it was found that shrimp vaccinated with recombinant DNA showed a longer protection effect (up to $50 \mathrm{~d}$ p.v.), whereas organisms vaccinated with the envelope protein VP28 were protected for a shorter period (14 d p.v.) [105]. Furthermore, those organisms vaccinated with recombinant DNA encoding VP28 showed enhanced levels of prophenoloxidase and superoxide dismutase, suggesting that these immunological parameters may contribute to confer resistance to shrimp against WSSV [99].

Nucleic acid-based vaccines seem to be a very promising and valuable approach against WSSV in the short-term. However, an important step in the rational design of a vaccine is to understand the immune correlates of protection. Unfortunately, the field of invertebrate immunology is severely delayed when compared to that of vertebrates, although the mechanistic understanding of the invertebrate immune system is rapidly evolving. Even when some interesting results have been obtained by the use of this strategy, several questions remain unanswered in the understanding of the phenomenon. Such useful approximations are not a desirable scheme from a scientific point of view. Besides, several preclinical studies coupled with large-scale trials still need to be performed to determine any possible risks of this approach.

\section{CONCLUDING REMARKS}

WSSV is a major causative agent that leads to high mortality rates in cultured shrimp. 
Despite its social and economic significance, several important issues related to the infection, propagation, and interaction between WSSV and its hosts at the cellular and molecular level, still remain to be elucidated. Studies are needed as well, to determine the true risks of this viral infection on wild populations of crustaceans. Thus, the development of robust detection methods and studies on the ecology of WSSV in wild populations should be a priority; otherwise a complete evaluation of the potential risk as a result of direct or indirect exposure of wild organisms to this virus will be impractical.

Today we know much more about this viral disease than a few years ago. However, it remains difficult to have a complete understanding of this phenomenon, since serious limitations set the direction of the research. Of course, a broad-based perspective of the subject, analyzing several issues (including immune evasion and host immune response) will shed light on possible effective strategies to overcome this important viral infection. Thus, studies related to WSSV prevention and control should be considered as essential by those involved in this economic activity and the scientific community.

Fortunately, the field of marine viruses and the interactions with their respective hosts is still at a relatively early stage, which gives valuable and exciting opportunities for research.

Acknowledgements. This work was funded by the Consejo Nacional de Ciencia y Tecnología (CONACyT), México, for grant 102744 (to ASP). Thanks are also due to the supportive staff of the Laboratorio de Sanidad Acuícola (CIBNOR, Hermosillo) particularly to Dr Jorge Hernández and MVZ Fernando Mendoza, and to Gerardo Hernández García for graphics assistance.

\section{REFERENCES}

[1] Balasubramanian G., Sarathi M., Venkatesan C., Thomas J., Sahul-Hameed A.S., Oral administration of antiviral plant extract of Cynodon dactylon on a large scale production against white spot syndrome virus (WSSV) in Penaeus monodon, Aquaculture (2008) 279:2-5

[2] Bang M.L., Centner T., Fornoff F., Geach A.J., Gotthardt M., McNabb M., et al., The complete gene sequence of titin, expression of an unusual approximately $700-\mathrm{kDa}$ titin isoform, and its interaction with obscurin identify a novel Z-line to I-band linking system, Circ. Res. (2001) 89:1065-1072.

[3] Bonnichon V., Lightner D.V., Bonami J.R., Viral interference between infectious hypodermal and hematopoietic necrosis virus and white spot syndrome virus in Litopenaeus vannamei, Dis. Aquat. Organ. (2006) 72:179-184.

[4] Bull J.J., Virulence, Evolution (1994) 48:14231437.

[5] Cai S., Huang J., Wang C., Song X., Sun X., Yu J., et al., Epidemiological studies on explosive epidemic disease of prawn 1993-1994, J. Fish. China (1995) 19:112-117.

[6] Carreras C.W., Santi D.V., The catalytic mechanism and structure of thymidylate synthase, Annu. Rev. Biochem. (1995) 64:721-762.

[7] Chaivisuthangkura P., Phattanapaijitkul P., Thammapalerd N., Rukpratanporn S., Longyant S., Sithigorngul W., Sithigorngul P., Development of a polyclonal antibody specific to VP19 envelope protein of white spot syndrome virus (WSSV) using a recombinant protein preparation, J. Virol. Methods (2006) 133:180-184.

[8] Chang C.F., Su M.S., Chen H.Y., Lo C.F., Kou G.H., Liao I.C., Effect of dietary $\beta$-1,3-glucan on resistance to white spot syndrome virus (WSSV) in postlarval and juvenile Penaeus monodon, Dis. Aquat. Organ. (1999) 36:163-168.

[9] Chang P.H., Chen H.C., Wang Y.C., Detection of white spot associated baculovirus in experimentally infected wild shrimp, crab and lobsters by in situ hybridization, Aquaculture (1998) 164:233-242.

[10] Chang P.S., Lo C.F., Wang Y.C., Kou G.H., Identification of white spot syndrome associated baculovirus (WSBV) target organs in the shrimp Penaeus monodon by in situ hybridization, Dis. Aquat. Organ. (1996) 27:131-139.

[11] Chang Y.S., Peng S.E., Wang H.C., Hsu H.C., Ho C.H., Wang C.H., et al., Sequencing and amplified restriction fragment length polymorphism analysis of ribonucleotide reductase large subunit gene of the white spot syndrome virus in blue crab (Callinectes sapidus) from American coastal waters, Mar. Biotechnol. (NY) (2001) 3:163-171.

[12] Chen J., Li Z., Hew C.L., Characterization of a novel envelope protein WSV010 of shrimp white spot syndrome virus and its interaction with a major viral structural protein VP24, Virology (2007) 364: 208-213.

[13] Chen L.L., Leu J.H., Huang C.J., Chou C.M., Chen S.M., Wang C.H., et al., Identification of a nucleocapsid protein (VP35) gene of shrimp white 
spot syndrome virus and characterization of the motif important for targeting VP35 to the nuclei of transfected insect cells, Virology (2002) 293:44-53.

[14] Chen L.L., Wang H.C., Huang C.J., Peng S.E., Chen Y.G., Lin S.J., et al., Transcriptional analysis of the DNA polymerase gene of shrimp white shrimp syndrome virus, Virology (2002) 301:136-147.

[15] Chen W.Y., Ho K.C., Leu J.H., Liu K.F., Wang H.C., Kou G.H., Lo C.F., WSSV infection activates STAT in shrimp, Dev. Comp. Immunol. (2008) 32:1142-1150.

[16] Cherbas L., Cherbas P., The arthropod initiator: the capsite consensus plays an important role in transcription, Insect Biochem. Mol. Biol. (1993) 23:81-90.

[17] Chou H.Y., Huang C.Y., Wang C.H., Chiang H.C., Lo C.F., Pathogenicity of a baculovirus infection causing white spot syndrome in cultured Penaeid shrimp in Taiwan, Dis. Aquat. Organ. (1995) 23: 165-173.

[18] Chou H.Y., Huang C.Y., Lo C.F., Kou G.H., Studies on transmission of white spot syndrome associated baculovirus (WSBV) in Penaeus monodon and $P$. japonicus via waterborne contact and oral ingestion, Aquaculture (1998) 164:263-276.

[19] Citarasu T., Sivaram V., Immanuel G., Rout N., Murugan V., Influence of selected Indian immunostimulant herbs against white spot syndrome virus (WSSV) infection in black tiger shrimp, Penaeus monodon with reference to haematological, biochemical and immunological changes, Fish Shellfish Immunol. (2006) 21:372-384.

[20] Corbel V., Zuprizal, Shi Z., Huang C., Sumartono, Arcier J.M., Bonami J.R., Experimental infection of European crustaceans with white spot syndrome virus (WSSV), J. Fish Dis. (2001) 24: 377-382.

[21] Di Leonardo V.A., Bonnichon V., Roch P., Parrinello N., Bonami J.R., Comparative WSSV infection routes in shrimp genera Marsupenaeus and Palaemon, J. Fish Dis. (2005) 28:565-569.

[22] Dieu B.T.M., Marks H., Siebenga J.J., Goldbach R.W., Zuidema D., Duong T.P., Vlak J.M., Molecular epidemiology of white spot syndrome virus within Vietnam, J. Gen. Virol. (2004) 85:3607-3618.

[23] Durand D., Lightner D.V., Nunan L.M., Redman R.M., Mari J., Bonami J.R., Application of gene probes as diagnostic tools for White Spot Baculovirus (WSBV) of Penaeid shrimp, Dis. Aquat. Organ. (1996) 27:59-66.

[24] Durand S., Lightner D.V., Redman R.M., Bonami J.R., Ultrastructure and morphogenesis of white spot syndrome baculovirus (WSSV), Dis. Aquat. Organ. (1997) 29:205-211.
[25] Durand S.V., Lightner D.V., Quantitative real time PCR for the measurement of white spot syndrome virus in shrimp, J. Fish Dis. (2002) 25:381-389.

[26] Edgerton B.F., Susceptibility of the Australian freshwater crayfish Cherax destructor albidus to white spot syndrome virus (WSSV), Dis. Aquat. Organ. (2004) 59:187-193.

[27] Flegel T.W., Special topic review: major viral diseases of the black tiger prawn (Penaeus monodon) in Thailand, World J. Microbiol. Biotechnol. (1997) 13:433-442.

[28] Galaviz-Silva L., Molina-Garza Z.J., AlcocerGonzalez J.M., Rosales-Encinas J.L., Ibarra-Gamez C., White spot syndrome virus genetic variants detected in Mexico by a new multiplex PCR method, Aquaculture (2004) 242:53-68.

[29] Gao H., Wang Y., Li N., Peng W.P., Sun Y., Tong G.Z., Qiu H.J., Efficient gene delivery into mammalian cells mediated by a recombinant baculovirus containing a whispovirus iel promoter, a novel shuttle promoter between insect cells and mammalian cells, J. Biotechnol. (2007) 131:138-143.

[30] Guan Y., Yu Z., Li C., The effects of temperature on white spot syndrome virus infections in Marsupenaeus japonicus, J. Invertebr. Pathol. (2003) 83: 257-260.

[31] Guoxing Z., Yalin S., Kai Z., Zhi C., Bacilliform virus infection in cultured Chinese shrimp, Penaeus orientalis, in China, J. Mar. Biotechnol. (1997) 5: 113-118.

[32] Han F., Xu J., Zhang X., Characterization of an early gene $(w s v 477)$ from shrimp white spot syndrome virus (WSSV), Virus Genes (2007) 34:193-198.

[33] Han F., Zhang X., Characterization of a rasrelated nuclear protein (Ran protein) up-regulated in shrimp antiviral immunity, Fish Shellfish Immunol. (2007) 23:937-944

[34] Hao N.V., Thuy D.T., Loan L.D.T., Phi T.T., Phuoc L.H., Duong H.H.T., et al., Presence of the two viral pathogens WSSV and MBV in three wild shrimp species (Penaeus indicus, Metapenaeus ensis, Metapenaeus lysianassa) cultured in the mangrove forest of Ca Mau Province, Asian Fish. Sci. (1999) 12: 309-325.

[35] Hasson K.W., Fan Y., Reisinger T., Venuti J., Varner P.W., White-spot syndrome virus (WSSV) introduction into the Gulf of Mexico and Texas freshwater systems through imported, frozen baitshrimp, Dis. Aquat. Organ. (2006) 71:91-100.

[36] Hauton C., Smith V.J., Adaptive immunity in invertebrates: a straw house without a mechanistic foundation, BioEssays (2007) 29:1138-1146. 
[37] He F., Fenner B.J., Godwin A.K., Kwang J., White spot syndrome virus open reading frame 222 encodes a viral E3 ligase and mediates degradation of a host tumor suppressor via ubiquitination, J. Virol. (2006) 80:3884-3892.

[38] He F., Kwang J., Identification and characterization of a new E3 ubiquitin ligase in white spot syndrome virus involved in virus latency, Virol. J. (2008) 5:1-8.

[39] Huang C., Zhang X., Lin Q., Xu X., Hu Z., Hew C.L., Proteomic analysis of shrimp white spot syndrome viral proteins and characterization of a novel envelope protein VP466, Mol. Cell. Proteomics (2002) $1: 223-231$.

[40] Huang C.H., Zhang L.R., Zhang J.H., Xiao L.H., Wu Q.J., Chen D.H., Li J.K.K., Purification and characterization of white spot syndrome virus (WSSV) produced in an alternate host: crayfish, Cambarus clarkii, Virus Res. (2001) 76:115-125.

[41] Huang J., Cai S., Song X., Wang C., Yu J., Yang C., Study on artificial infection for Penaeus chinensis by the pathogen of the explosive epidemic disease of shrimp, Mar. Fish Res. (1995) 16:51-58.

[42] Huang R., Xie Y., Zhang J., Shi Z., A novel envelope protein involved in white spot syndrome virus infection, J. Gen. Virol. (2005) 86:1357-1361.

[43] Inouye K., Yamano K., Ikeda N., Kimura T., Nakano H., Momoyama K., et al., The Penaeid rodshaped DNA virus (PRDV), which causes Penaeid acute viremia (PAV), Fish Pathol. (1996) 31:39-45.

[44] Jiravanichpaisal P., Bangyeekhun E., Söderhäll K., Söderhäll I., Experimental infection of white spot syndrome virus in freshwater crayfish Pacifastacus leniusculus, Dis. Aquat. Organ. (2001) 47:151-157.

[45] Jiravanichpaisal P., Söderhäll K., Söderhäll I., Effect of water temperature on the immune response and infectivity pattern of white spot syndrome virus (WSSV) in freshwater crayfish, Fish Shellfish Immunol. (2004) 17:265-275.

[46] Jiravanichpaisal P., Söderhäl K., Söderhäl I., Characterization of white spot syndrome virus replication in in vitro-cultured haematopoietic stem cells of freshwater crayfish, Pacifastacus leniusculus, J. Gen. Virol. (2006) 87:847-854.

[47] Jiravanichpaisal P., Sricharoen S., Söderhäl I., Söderhäl K., White spot syndrome virus (WSSV) interaction with crayfish haemocytes, Fish Shellfish Immunol. (2006) 20:718-727.

[48] Kanchanaphum P., Wongteerasupaya C., Sitidilokratana N., Boonsaeng V., Panyim S., Tassanakajon A., et al., Experimental transmission of white spot syndrome virus (WSSV) from crabs to shrimp Penaeus monodon, Dis. Aquat. Organ. (1998) 34:1-7.
[49] Kang S.T., Leu J.H., Wang H.C., Chen L.L., Kou G.H., Lo C.F., Polycistronic mRNAs and internal ribosome entry site elements (IRES) are widely used by white spot syndrome virus (WSSV) structural protein genes, Virology (2009) 387:353-363.

[50] Kasornchandra J., Boonyaratpalin S., Primary shrimp cell culture: applications for studying white spot syndrome virus (WSSV), in: Flegel T.W. (Ed.), Advances in shrimp biotechnology, National Center for Genetic Engineering and Biotechnology, Bangkok, 1998, pp. 273-276.

[51] Khadijah S., Neo S.Y., Hossain M.S., Miller L.D., Mathavan S., Kwang J., Identification of white spot syndrome virus latency-related genes in specificpathogen-free shrimps by use of a microarray, J. Virol. (2003) 77:10162-10167.

[52] Kim C.S., Kosuke Z., Nam Y.K., Kim S.K., Kim K.H., Protection of shrimp (Penaeus chinensis) against white spot syndrome virus (WSSV) challenge by double-stranded RNA, Fish Shellfish Immunol. (2007) 23:242-246.

[53] Lan Y., Lu W., Xu X., Genomic instability of prawn white spot bacilliform virus (WSBV) and its association to virus virulence, Virus Res. (2002) 90:269-274.

[54] Lan Y., Xu X., Yang F., Zhang X., Transcriptional profile of shrimp white spot syndrome virus (WSSV) genes with DNA microarray, Arch. Virol. (2006) 151:1723-1733.

[55] Lei K., Li F., Zhang M., Yang H., Luo T., Xu X., Difference between hemocyanin subunits from shrimp Penaeus japonicus in anti-WSSV defense, Dev. Comp. Immunol. (2008) 32:808-813.

[56] Leu J.H., Tsai J.M., Wang H.C., Wang A.H.J., Wang C.H., Kou G.H., Lo C.F., The unique stacked rings in the nucleocapsid of the white spot syndrome virus virion are formed by the major structural protein VP664, the largest viral structural protein ever found, J. Virol. (2005) 79:140-149.

[57] Leu J.H., Wang H.C., Kou G.H., Lo C.F., Penaeus monodon caspase is targeted by a white spot syndrome virus anti-apoptosis protein, Dev. Comp. Immunol. (2008) 32:476-486.

[58] Li F., Li M., Ke W., Ji Y., Bian X., Yan X., Identification of the immediate-early genes of white spot syndrome virus, Virology (2009) 385:267-274.

[59] Li L., Lin S., Yang F., Functional identification of the non-specific nuclease from white spot syndrome virus, Virology (2005) 337:399-406.

[60] Li L., Xie X., Yang F., Identification and characterization of a prawn white spot syndrome virus gene that encodes an envelope protein VP31, Virology (2005) 340:125-132. 
[61] Li Q., Zhang J., Chen Y., Yang F., White spot syndrome virus (WSSV) infectivity for Artemia at different developmental stages, Dis. Aquat. Organ. (2003) 57:261-264.

[62] Li Q., Chen Y., Yang F., Identification of a collagen-like protein gene from white spot syndrome virus, Arch. Virol. (2004) 149:215-223.

[63] Li Y., Miller L.K., Expression and functional analysis of a baculovirus gene encoding a truncated protein kinase homolog, Virology (1995) 206: 314-323.

[64] Li Z., Lin Q., Chen J., Wu J.L., Lim T.W., Loh S.S., et al., Shotgun identification of the structural proteome of shrimp white spot syndrome virus and iTRAQ differentiation of envelope and nucleocapsid subproteomes, Mol. Cell. Proteomics (2007) 6:16091620 .

[65] Li Q., Pan D., Zhang J.H., Yang F., Identification of the thymidylate synthase within the genome of white spot syndrome virus, J. Gen. Virol. (2004) 85:2035-2044.

[66] Liang Y., Huang J., Song X.L., Zhang P.J., $\mathrm{Xu}$ H.S., Four viral proteins of white spot syndrome virus (WSSV) that attach to shrimp cell membranes, Dis. Aquat. Organ. (2005) 66:81-85.

[67] Lightner D.V., A handbook of shrimp pathology and diagnostic procedures for disease of cultured Penaeid shrimp, World Aquac. Soc, Baton Rouge, Louisiana, USA, 1996. p. 304.

[68] Lightner D.V., Hasson K.W., White B.L., Redman R.M., Experimental infection of western hemisphere Penaeid shrimp with Asian white spot syndrome virus and Asian yellow head virus, J. Aquat. Anim. Health (1998) 10:271-281.

[69] Lin S.T., Chang Y.S., Wang H.C., Tzeng H.F., Chang Z.F., Lin J.Y., et al., Ribonucleotide reductase of shrimp white spot syndrome virus (WSSV): expression and enzymatic activity in a baculovirus/ insect cell system and WSSV-infected shrimp, Virology (2002) 304:282-290.

[70] Liu W.J., Yu H.T., Peng S.E., Chang Y.S., Pien H.W., Lin C.J., et al., Cloning, characterization, and phylogenetic analysis of shrimp white spot syndrome virus gene that encodes a protein kinase, Virology (2001) 289:362-377.

[71] Liu W.J., Chang Y.S., Wang C.H., Kou G.H., Lo C.F., Microarray and RT-PCR screening for white spot syndrome virus immediate early genes in cycloheximide-treated shrimp, Virology (2005) 334:327-341.

[72] Liu W.J., Chang Y.S., Wang A.H.J., Kou G.H., Lo C.F., White spot syndrome virus annexes a shrimp STAT to enhance expression of the immediate-early gene ie1, J. Virol. (2007) 81:1461-1471.
[73] Liu W.J., Chang Y.S., Wang H.C., Leu J.H., Kou G.H., Lo C.F., Transactivation, dimerization, and DNA-binding activity of white spot syndrome virus immediate early protein IE1, J. Virol. (2008) 82:11362-11373.

[74] Liu X., Yang F., Identification and function of a shrimp white spot syndrome virus (WSSV) gene that encodes a dUTPase, Virus Res. (2005) 110:21-30.

[75] Liu Y., Wu J., Song J., Sivaraman J., Hew C.L., Identification of a novel nonstructural protein, VP9, from white spot syndrome virus: its structure reveals a ferredoxin fold with specific metal binding sites, J. Virol. (2006) 80:10419-10427.

[76] Lo C., Ho C., Peng S., Chen C., Hsu H., Chiu Y., et al., White spot syndrome baculovirus (WSBV) detected in cultured and captured shrimp, crabs and other arthropods, Dis. Aquat. Organ. (1996) 27:215225

[77] Lo C.F., Ho C.H., Chen C.H., Liu K.F., Chiu Y.L., Yeh P.Y., et al., Detection and tissue tropism of white spot syndrome baculovirus (WSSV) in captured brooders of Penaeus monodon with a special emphasis on reproductive organs, Dis. Aquat. Organ. (1997) 30:53-72.

[78] Lotz J.M., Soto M.A., Model of white spot syndrome virus (WSSV) epidemics in Litopenaeus vannamei, Dis. Aquat. Organ. (2002) 50:199-209.

[79] Lu C.P., Zhu S., Guo F.S., Wu S.Y., Electron microscopic observation on a non-occluded baculolike virus in shrimps, Arch. Virol. (1997) 142:20732078.

[80] Lu L., Kwang J., Identification of a novel shrimp protein phosphatase and its association with latencyrelated ORF427 of white spot syndrome virus, FEBS Lett. (2004) 577:141-146.

[81] Lu L., Wang H., Manopo I., Yu L., Kwang J., Baculovirus-mediated promoter assay and transcriptional analysis of white spot syndrome virus orf427 gene, Virol. J. (2005) 2:71-77.

[82] Luo T., Li F., Lei K., Xu X., Genomic organization, promoter characterization and expression profiles of an antiviral gene $P m A V$ from the shrimp Penaeus monodon, Mol. Immunol. (2007) 44:15161523.

[83] Maeda M., Itami T., Furumoto A., Hennig O., Imamura T., Kondo M., et al., Detection of Penaeid rod-shaped DNA virus (PRDV) in wild-caught shrimp and other crustaceans, Fish Pathol. (1998) 33: 373-380.

[84] Marks H., Mennens M., Vlak J.M., van Hulten M.C.W., Transcriptional analysis of the white spot syndrome virus major virion protein genes, J. Gen. Virol. (2003) 84:1517-1523. 
[85] Marks H., Golodbach R.W., Vlak J.M., van Hulten M.C.W., Genetic variation isolates of white spot syndrome virus, Arch. Virol. (2004) 149:673693.

[86] Marks H., Ren X.Y., Sandbrink H., van Hulten C.W., Vlak J.M., In silico identification of putative promoter motifs of white spot syndrome virus, BMC Bioinformatics (2006) 7:309.

[87] Melena J., Bayot B., Betancourt I., Amano Y., Panchana F., Alday V., et al., Pre-exposure to infectious hypodermal and haematopoietic necrosis virus or to inactivated white spot syndrome virus (WSSV) confers protection against WSSV in Penaeus vannamei (Boone) post-larvae, J. Fish Dis. (2006) 29: 589-600.

[88] Nakano H., Koube H., Umezawa S., Momoyama K., Hiraoka M., Inouye K., Oseko S., Mass mortalities of cultured kuruma shrimp, Penaeus japonicus, in Japan in 1993: epizootiological survey and infection trials, Fish Pathol. (1994) 29:135-139.

[89] Namikoshi A., Wu J.L., Yamashita T., Nishizawa T., Nishioka T., Arimoto M., Muroga K., Vaccination trials with Penaeus japonicus to induce resistance to white spot syndrome virus, Aquaculture (2004) 229:25-35.

[90] Ongvarrasopone C., Chanasakulmiyon M., Sritunyalucksana K., Panyim S., Suppression of PmRab7 by dsRNA inhibits WSSV or YHV infection in shrimp, Mar. Biotechnol. (2008) 10:374-381.

[91] Otta S.K., Shubha G., Joseph B., Chakraborty A., Karunasagar I., Karunasagar I., Polymerase chain reaction (PCR) detection of white spot syndrome virus (WSSV) in cultured and wild crustaceans in India, Dis. Aquat. Organ. (1999) 38:67-70.

[92] Pan D., He N., Yang Z., Liu H., Xu X., Differential gene expression profile in hepatopancreas of WSSV-resistant shrimp (Penaeus japonicus) by suppression subtractive hybridization, Dev. Comp. Immunol. (2005) 29:103-112.

[93] Passarelli A.L., Guarino L.A., Baculovirus late and very late gene regulation, Curr. Drug Targets (2007) 8:1103-1115.

[94] Peng S.E., Lo C.F., Ho C.H., Chang C.F., Kou G.H., Detection of white spot baculovirus (WSBV) in giant freshwater prawn, Macrobrachium rosenbergii, using polymerase chain reaction, Aquaculture (1998) 164:253-262.

[95] Pradeep B., Shekar M., Karunasagar I., Karunasagar I., Characterization of variable genomic regions of Indian white spot syndrome virus, Virology (2008) 376:24-30.

[96] Rahman M.N., Corteel M., Wille M., AldaySanz V., Pensaert M.B., Sorgeloos P., Nauwynck H.J., The effect of raising water temperature to $33{ }^{\circ} \mathrm{C}$ in
Penaeus vannamei juveniles at different stages of infection with white spot syndrome virus (WSSV), Aquaculture (2007) 272:240-245.

[97] Rajan P.R., Ramasamy P., Purushothaman V., Brennan G.P., White spot baculovirus syndrome in the Indian shrimp Penaeus monodon and $P$. indicus, Aquaculture (2000) 184:31-44.

[98] Rajendran K.V., Vijayan K.K., Santiago T.C., Krol R.M., Experimental host range and histopathology of white spot syndrome virus (WSSV) infection in shrimp, prawns, crabs and lobsters from India, J. Fish Dis. (1999) 22:183-191.

[99] Rajesh-Kumar S., Ishaq-Ahamed V.P., Sarathi M., Nazeer-Basha A., Sahul-Hameed A.S., Immunological responses of Penaeus monodon to DNA vaccine and its efficacy to protect shrimp against white spot syndrome virus (WSSV), Fish Shellfish Immunol. (2008) 24:467-478.

[100] Rameshthangam P., Ramasamy P., Antiviral activity of bis(2-methylheptyl)phthalate isolated from Pongamia pinnata leaves against white spot syndrome virus of Penaeus monodon Fabricius, Virus Res. (2007) 126:38-44.

[101] Rijiravanich A., Browdy C.L., Withyachumnarnkul B., Knocking down caspase-3 by RNAi reduces mortality in Pacific white shrimp Penaeus (Litopenaeus) vannamei challenged with a low dose of white-spot syndrome virus, Fish Shellfish Immunol. (2008) 24:308-313.

[102] Robalino J., Browdy C.L., Prior S., Metz A., Parnell P., Gross P., Warr G., Induction of antiviral immunity by double-stranded RNA in a marine shrimp invertebrate, J. Virol. (2004) 78:10442-10448.

[103] Robalino J., Bartlet T., Shepard E., Prior S., Jaramillo G., Scura E., et al., Double-stranded RNA induces sequence-specific antiviral silencing in addition to nonspecific immunity in a marine shrimp: convergence of RNA interference and innate immunity in the invertebrate antiviral response?, J. Virol. (2005) 79:13561-13571.

[104] Robalino J., Bartlett T.C., Chapman R.W., Gross P.S., Browdy C.L., Warr G.W., Double-stranded RNA and antiviral immunity in marine shrimp: inducible host mechanisms and evidence for the evolution of viral counter-responses, Dev. Comp. Immunol. (2007) 31:539-547.

[105] Rout N., Kumar S., Jaganmohan S., Murugan V., DNA vaccines encoding viral envelope proteins confer protective immunity against WSSV in black tiger shrimp, Vaccine (2007) 25:2778-2786.

[106] Sahtout A.H., Hassan M.D., Shariff M., DNA fragmentation, an indicator of apoptosis, in cultured black tiger shrimp Penaeus monodon infected with 
white spot syndrome virus (WSSV), Dis. Aquat. Organ. (2001) 44:155-159.

[107] Sahul-Hameed A.S., Charles M.X., Anikumar M., Tolerance of Macrobrachium rosenbergii to white spot syndrome virus, Aquaculture (2000) 183:207-213.

[108] Sahul-Hameed A.S., Yoganandhan K., Sathish S., Rasheed M., Murugan V., Jayarama K., White spot syndrome virus (WSSV) in two species of freshwater crabs (Paratelphusa hydrodomus and P. pulvinata), Aquaculture (2001) 201:179-186.

[109] Sahul-Hameed A.S., Murthi B.L.M., Rasheed M., Sathish S., Yoganandhan K., Murugan V., Jayaraman K., An investigation of Artemia as a possible vector for white spot syndrome virus (WSSV) transmission to Penaeus indicus, Aquaculture (2002) 204:1-10.

[110] Sahul-Hameed A.S., Balasubramanian G., Syed-Musthaq S., Yoganandhan K., Experimental infection of twenty species of Indian marine crabs with white spot syndrome virus (WSSV), Dis. Aquat. Organ. (2003) 57:157-161.

[111] Sahul-Hameed A.S., Sarathi M., Sudhakaran R., Balasubramanian G., Syed-Musthaq S., Quantitative assessment of apoptotic hemocytes in white spot syndrome virus (WSSV)-infected Penaeid shrimp, Penaeus monodon and Penaeus indicus, by flow cytometric analysis, Aquaculture (2006) 201:179-186.

[112] Samal A., Schormann N., Cook W.J., DeLucas L.J., Chattopadhyay D., Structures of vaccinia virus dUTPase and its nucleotide complexes, Acta Crystallogr. (2007) 63D:571-580.

[113] Sarathi M., Simon M.C., Ishaq-Ahmed V.P., Rajesh-Kumar S., Sahul-Hameed A.S., Silencing VP28 gene of white spot syndrome virus of shrimp by bacterially expressed dsRNA, Mar. Biotechnol. (2008) 10:198-206.

[114] Sarathi M., Simon M.C., Venkatesan C., SahulHameed A.S., Oral administration of bacterially expressed VP28dsRNA to protect Penaeus monodon from white spot syndrome virus, Mar. Biotechnol. (2008) 10:242-249.

[115] Shahadat-Hossain M., Khadijah S., Kwang J., Characterization of ORF89: a latency-related gene of white spot syndrome virus, Virology (2004) 325:106-115.

[116] Shahadat-Hossain M.S., Chakraborty A., Joseph B., Otta S.K., Karunasagar I., Karunasagar I., Detection of new hosts for white spot syndrome virus of shrimp using nested polymerase chain reaction, Aquaculture (2001) 198:1-11.

[117] Shi Z., Huang C., Zhang J., Chen D., Bonami J.R., White spot syndrome virus (WSSV) experimental infection of the freshwater crayfish Cherax quadricarinatus, J. Fish Dis. (2000) 23:285-288.

[118] Sritunyalucksana K., Wannapapho W., Lo C.F., Flegel T.W., PmRab7 is a VP28-binding protein involved in white shrimp syndrome virus infection in shrimp, J. Virol. (2006) 80:10734-10742.

[119] Supamattaya K., Hoffmann R.W., Boonyaratpalin S., Kanchanaphum P., Experimental transmission of white spot syndrome virus (WSSV) from black tiger shrimp Penaeus monodon to the sand crab Portunus pelagicus, mud crab Scylla serrata and krill Acetes sp., Dis. Aquat. Organ. (1998) 32:79-85.

[120] Suttle C.A., Marine viruses: major players in the global ecosystem, Nat. Rev. Microbiol. (2007) 5:801-812.

[121] Syed-Musthaq S., Sudhakaran R., Balasubramanian G., Sahul-Hameed A.S., Experimental transmission and tissue tropism of white spot syndrome virus (WSSV) in two species of lobsters, Panulirus homarus and Panulirus ornatus, J. Invertebr. Pathol. (2006) 93:75-80.

[122] Takahashi Y., Fukoda K., Kondo M., Chongthaleong A., Nishi K., Nishimura M., et al., Detection and prevention of WSSV infection in cultured shrimp, Asian Aquacult. Mag. (2003) 25-27.

[123] Tang X., Wu J., Siravaman J., Hew C.L., Crystal structures of major envelope proteins VP26 and VP28 from white spot syndrome virus shed light on their evolutionary relationship, J. Virol. (2007) 81:6709-6717.

[124] Tsai J.M., Wang H.C., Leu J.H., Hsiao H.H., Wang A.H.J., Kou G.H., Lo C.F., Genomic and proteomic analysis of thirty-nine structural proteins of shrimp white spot syndrome virus, J. Virol. (2004) 78:11360-11370.

[125] Tsai M.F., Lo C.F., van Hulten M.C.W., Tzeng H.F., Chou C.M., Huang C.J., et al., Transcriptional analysis of the ribonucleotide reductase genes of shrimp white spot syndrome virus, Virology (2000) 277:92-99.

[126] Tsai M.F., Yu T.H., Tzeng H.F., Leu J.H., Chou C.M., Huang H.J., et al., Identification and characterization of a shrimp white spot syndrome virus (WSSV) gene that encodes a novel chimeric polypeptide of cellular-type thymidine kinase and thymidylate kinase, Virology (2000) 277:100-110.

[127] Tzeng H.F., Chang Z.F., Peng S.E., Wang C.H., Lin J.Y., Kou G.H., Lo C.F., Chimeric polypeptide of thymidine kinase and thymidylate kinase of shrimp white spot syndrome virus: thymidine kinase activity of the recombinant protein expressed in a baculovirus/ insect cell system, Virology (2002) 229:248-255.

[128] Unzueta-Bustamante M.L., Silveira-Cofficny R., Prieto A.A., Aguirre-Guzmán G., Vázquez-Juarez R., 
Susceptibilidad de Litopenaeus schmitti y Cherax quadricarinatus al virus del sindrome de la mancha blanca (WSSV), Cienc. Mar. (2004) 30:537-545.

[129] Van Hulten M.C.W., Westenberg M., Goodal S.D., Vlak J.M., Identification of two major virion protein genes of white spot syndrome virus of shrimp, Virology (2000) 266:227-236.

[130] Van Hulten M.C.W., Tsai M.F., Schipper C.A., Lo C.F., Kou G.H., Vlak J.M., Analysis of a genomic segment of white spot syndrome virus of shrimp containing ribonucleotide reductase genes and repeat regions, J. Gen. Virol. (2000) 81:307-316.

[131] Van Hulten M.C.W., Vlak J.M., Identification and phylogeny of a protein kinase gene of white spot syndrome virus, Virus Genes (2001) 22:201-207.

[132] Van Hulten M.C.W., Witteveldt J., Peters S., Kloosterboer N., Tarchini R., Fiers M., et al., The white spot syndrome virus DNA genome sequence, Virology (2001) 286:7-22.

[133] Van Hulten M.C.W., Witteveldt J., Snippe M., Vlak J.M., White spot syndrome virus envelope protein VP28 is involved in the systemic infection of shrimp, Virology (2001) 285:228-233.

[134] Van Hulten M.C.W., Reijns M., Vermeesch A.M.G., Zandbergen F., Vlak J.M., Identification of VP19 and VP15 of white spot syndrome virus (WSSV) and glycosylation status of the WSSV major structural proteins, J. Gen. Virol. (2002) 83:257-265.

[135] Vanpatten K.A., Nunan L.M., Lightner D.V., Seabirds as potential vectors of Penaeid shrimp viruses and the development of a surrogate laboratory model utilizing domestic chickens, Aquaculture (2004) 241:31-46.

[136] Vaseeharan B., Anand T.P., Murugan T., Chen J.C., Shrimp vaccination trials with the VP292 protein of white spot syndrome virus, Lett. Appl. Microbiol. (2006) 43:137-142.

[137] Venegas C.A., Nonaka L., Mushiake K., Nishizawa T., Muroga K., Quasi-immune response of Penaeus japonicus to Penaeid rod-shaped DNA virus (PRDV), Dis. Aquat. Organ. (2000) 42:83-89.

[138] Vidal O.M., Granja C.B., Aranguren F., Brock J.A., Salazar M., A profound effect of hyperthermia on survival of Litopenaeus vannamei juveniles infected with white spot syndrome virus, J. World Aquacult. Soc. (2001) 32:364-372.

[139] Vijayan K.K., Raj V.S., Balasubramanian C.P., Alavandi S.V., Sekhar V.T., Santiago T.C., Polychaete worms - a vector for white spot syndrome virus (WSSV), Dis. Aquat. Organ. (2005) 63:107-111.

[140] Wang C.H., Lo C.F., Leu J.H., Chou C.M., Yeh P.Y., Chou H.Y., et al., Purification and genomic analysis of baculovirus associated with white spot syndrome (WSBV) of Penaeus monodon, Dis. Aquat. Organ. (1995) 23:239-242.

[141] Wang H.C., Lin A.T., Yii D.M., Chang Y.S., Kou G.H., Lo C.F., DNA microarrays of the white spot syndrome virus genome: genes expressed in the gills of infected shrimp, Mar. Biotechnol. (2003) 6:S106-S111.

[142] Wang H.C., Wang H.C., Kou G.H., Lo C.F., Huang W.P., Identification of icp 11, the most highly expressed gene of shrimp white spot syndrome virus (WSSV), Dis. Aquat. Organ. (2007) 74:179-189.

[143] Wang H.C., Wang H.C., Ko T.P., Lee Y.M., Leu J.H., Ho C.H., et al., White spot syndrome virus protein ICP11: a histone-binding DNA mimic that disrupts nucleosome assembly, Proc. Natl. Acad. Sci. USA (2008) 105:20758-20763.

[144] Wang Q., White B.L., Redman R.M., Lightner D.V., Per os challenge of Litopenaeus vannamei postlarvae and Farfantepenaeus duorarum juveniles with six geographic isolates of white spot syndrome virus, Aquaculture (1999) 170:179-194.

[145] Wang Q., Poulos B.T., Lightner D.V., Protein analysis of geographic isolates of shrimp white spot syndrome virus, Arch. Virol. (2000) 145:263-274.

[146] Wang Q., Nunan L.M., Lightner D.V., Identification of genomic variations among geographic isolates of white spot syndrome virus using restriction analysis and Southern blot hybridization, Dis. Aquat. Organ. (2000) 43:175-181.

[147] Wang Y.C., Lo C.F., Chang P.S., Kou G.H., Experimental infection of white spot baculovirus in some cultured and wild decapods in Taiwan, Aquaculture (1998) 164:221-231.

[148] Wang Y.G., Hassanm M.D., Shariff M., Zamri S.M., Chen X., Histopathology and cytopathology of white spot syndrome virus (WSSV) in cultured Penaeus monodon from peninsular Malaysia with emphasis on pathogenesis and the mechanism of white spot formation, Dis. Aquat. Organ. (1999) 22:1-11.

[149] Wang Z., Hu L., Yi G., Xu H., Qi Y., Yao L., ORF390 of white spot syndrome virus genome is identified as a novel anti-apoptosis gene, Biochem. Biophys. Res. Commun. (2004) 325:899-907.

[150] Wang Z., Chua H.K., Gusti A.A., He F., Fenner B., Manopo I., et al., RING-H2 protein WSSV249 from white spot syndrome virus sequesters a shrimp ubiquitin-conjugating enzyme, PvUbc, for viral pathogenesis, J. Virol. (2005) 79:8764-8772.

[151] Westenberg M., Heinhuis B., Zuidema D., Vlak J.M., siRNA injection induces sequence-independent protection in Penaeus monodon against white spot syndrome virus, Virus Res. (2005) 114:133-139. 
[152] Witteveldt J., van Hulten M.C.W., Vlak J.M., Identification and phylogeny of a non-specific nuclease gene of white spot syndrome virus of shrimp, Virus Genes (2001) 23:331-337.

[153] Witteveldt J., Vlak J.M., van Hulten M.C.W., Protection of Penaeus monodon against white spot syndrome virus using a WSSV subunit vaccine, Fish Shellfish Immunol. (2004) 16:571-579.

[154] Witteveldt J., Vermeesch A.M.G., Langenhof M., de Lang A., Vlak J.M., van Hulten M.C.W., Nucleocapsid protein VP15 is the basic DNA binding protein of white spot syndrome virus of shrimp, Arch. Virol. (2005) 150:1121-1133.

[155] Wongprasert K., Sangsuriya P., Phongdara A., Senapin S., Cloning and characterization of a caspase gene from black tiger shrimp (Penaeus monodon)infected with white spot syndrome virus (WSSV), J. Biotechnol. (2007) 131:9-19.

[156] Wongteerasupaya C., Vickers J.E., Sriurairatana S., Nash G.L., Alarajamorn A., Boonsaeng V., et al., A non-occluded, systemic baculovirus that occurs in cells of ectodermal and mesodermal origin and causes high mortality in the black tiger prawn Penaeus monodon, Dis. Aquat. Organ. (1995) 21:69-77.

[157] Wongteerasupaya C., Wongwisansri S., Boonsaeng V., Panyim S., Pratanpipat P., Nash G.L., et al., DNA fragment of Penaeus monodon baculovirus PmNOBII gives positive in situ hybridization with white-spot viral infections in six Penaeid shrimp species, Aquaculture (1996) 143:23-32.

[158] Wu C., Yang F., Localization studies of two white spot syndrome virus structural proteins VP51 and VP76, Virol. J. (2006) 3:1-8.

[159] Wu J.L., Nishioka T., Mori K., Nishizawa T., Muroga K., A time-course study on the resistance of Penaeus japonicus induced by artificial infection with white spot syndrome virus, Fish Shellfish Immunol. (2002) 13:391-403.

[160] Wu W., Zhang X., Characterization of a RabGTPase up-regulated in the shrimp Penaeus japonicus by virus infection, Fish Shellfish Immunol. (2007) 23:438-445.

[161] Wu W., Zong R., Xu H., Zhang X., Antiviral phagocytosis is regulated by a novel Rab-dependent complex in shrimp Penaeus japonicus, J. Proteome Res. (2008) 7:424-431.

[162] Xie X., Yang F., Interaction of white spot syndrome virus VP26 protein with actin, Virology (2005) 336:93-99.
[163] Xie X., Yang F., White spot syndrome virus VP24 interacts with VP28 and is involved in virus infection, J. Gen. Virol. (2006) 87:1903-1908.

[164] Xu J., Han F., Zhang X., Silencing shrimp white spot syndrome virus (WSSV) genes by siRNA, Antiviral Res. (2007) 73:126-131.

[165] Yan D.C., Dong S.L., Huang J., Yu X.M., Feng M.Y., Liu X.Y., White spot syndrome virus (WSSV) detected by $\mathrm{PCR}$ in rotifers and rotifer resting eggs from shrimp pond sediments, Dis. Aquat. Organ. (2004) 59:69-73.

[166] Yang F., He J., Lin X., Li Q., Pan D., Zhang X., $\mathrm{Xu} \mathrm{X}$., Complete genome sequence of shrimp white spot bacilliform virus, J. Virol. (2001) 75:1181111820 .

[167] Yi G., Wang Z., Qi Y., Yao L., Qian J., Hu L., VP28 of shrimp white spot syndrome virus is involved in the attachment and penetration into shrimp cells, J. Biochem. Mol. Biol. (2004) 37:726-734.

[168] Zhang M., Wang H., Li D., Xu X., A novel focal adhesion kinase from Marsupenaeus japonicus and its response to WSSV infection, Dev. Comp. Immunol. (2009) 33:533-539.

[169] Zhang X., Xu X., Hew C.L., The structure and function of a gene encoding a basic peptide from prawn white spot syndrome virus, Virus Res. (2001) 79:137-144.

[170] Zhang X., Huang C., Xu X., Hew C.L., Identification and localization of a prawn white spot syndrome virus gene that encodes an envelope protein, J. Gen. Virol. (2002) 83:471-477.

[171] Zhang X.B., Huang C.H., Xu X., Hew C.L., Transcription and identification of an envelope protein gene (p22) from shrimp white spot syndrome virus, J. Gen. Virol. (2002) 83:471-477.

[172] Zhu Y., Xie X., Yang F., Transcription and identification of a novel envelope protein (VP124) gene of shrimp white spot syndrome virus, Virus Res. (2005) 113:100-106

[173] Zhu Y., Ding Q., Yang F., Characterization of a homologous-region-binding protein from white spot syndrome virus by phage display, Virus Res. (2007) 125:145-152.

[174] Zhu Y.B., Li H.Y., Yang F., Identification of an envelope protein (VP39) gene from shrimp white spot syndrome virus, Arch. Virol. (2006) 151:71-82. 